Methods of Chemical

Analysis for Organic Waste

Constituents in Radioactive Materials: A Literature Review

S. A. Clauss

R. M. Bean

February 1993

Prepared for the U.S. Department of Energy under Contract DE-AC06-76RLO 1830

Pacific Northwest Laboratory

Operated for the U.S. Department of Energy by Battelle Memorial Institute 


\title{
DISCLAIMFR
}

This report was prepared as an account of work sponsored by an agency of the United States Government. Neither the United States Government nor any agency thereof, nor Battelle Memorial Institute, nor any of their employees, makes any warranty, expressed or implied, or assumes any legal liability or responsibility for the accuracy, completeness, or usefulness of any information, apparatus, product, or process disclosed, or represents that its use would not infringe privately owned rights. Reference herein to any specific commercial product, process, or service by trade name, trademark, manufacturer, or otherwise does not necessarily constitute or imply its endorsement, recommendation, or favoring by the United States Government or any agency thereof, or Battelle Memorial Institute. The views and opinions of authors expressed herein do not necessarily state or reflect those of the United States Government or any agency thereof.

\author{
PACIFIC NORTHWEST LABORATORY \\ operated by \\ BATTELLE MEMORIAL INSTITUTE \\ for the \\ UNITED STATES DEPARTMENT OF ENERGY \\ under Contract DE-AC06-76RLO 1830
}

Printed in the United States of America

Available to DOE and DOE contractors from the

Office of Scientific and Technical Information, P.O. Box 62, Oak Ridge, IN 37831; prices available from (615) 576-8401. FTS 626-8401.

Available to the public from the National Technical Information Service, U.S. Department of Commerce, 5285 Port Royal Rd., Springfield, VA 22161. 
PNL-8266

UC-510

\section{METHODS OF CHEMICAL ANALYSIS FOR ORGANIC WASTE CONSTITUENTS IN RADIOACTIVE MATERIALS: A LITERATURE REVIEW}

S. A. Clauss

R. M. Bean

February 1993

Prepared for

the U. S. Department of Energy

Under Contract DE-AC06-76RLO 1830

Pacific Northwest Laboratory

Richland, WA 99352 
Most of the waste generated during the production of defense materials at Hanford is presently stored in 177 underground tanks. Because of the many waste treatment processes used at Hanford, the operations conducted to move and consolidate the waste, and the long-term storage conditions at elevated temperatures and radiolytic conditions, little is known about most of the organic constituents in the tanks. The nature of the organic material is an important factor in the resolution of safety questions about some of the storage tanks. Organics are a factor in the production of hydrogen from storage tank 101-SY and represent an unresolved safety question in the case of tanks containing high organic carbon content. The nature of the organics has an effect upon the potential energy contained in the tanks.

In preparation for activities that will lead to the characterization of organic components in Hanford waste storage tanks, a thorough search of the literature has been conducted to identify those procedures that have been found useful for identifying and quantifying organic components in radioactive matrices. The information is to be used in the planning of method development activities needed to characterize the organics in tank wastes and will prevent duplication of effort in the development of needed methods.

The literature relating to organic analysis in waste matrices is sparse. The literature was searched through the American Chemical Society, U. S. Department of Energy (DOE) and Department of Defense (DoD) electronic databases, as well as manual searches through DOE and Hanford Methods Manuals, and the Hanford Library Report Archives. Through these searches, almost 400 references were identified through titles, abstracts, or keywords as potentially containing relevant material. Further investigation of these documents revealed that less than 60 items actually pertained to methods specific to, or modified for, analyzing organics in radioactive matrices. These items have formed the substance of the review.

Some publications pertaining to determination of organics in rad wastes were found that did not specify the details of the analytical methods used. These were included for their general interest and for completeness. The major body of the literature discussed in this report deals with analysis of organics in nuclear wastes or in nuclear waste burial sites. One-half of the 32 references included under nuclear wastes were produced at Hanford. The most important body of work describes the analysis of Hanford tank 
wastes. Various researchers have shown that a variety of organic chelators and their radiolytic or thermal decomposition products constitute a significant portion of the organic carbon in several wastes examined. Other organic constituents were also identified, most of which are not on the Environmental Protection Agency (EPA) list of priority pollutants. Another important contribution was from Oak Ridge National Laboratory. This work described in detail the modifications of standard EPA methods for the analysis of radioactive wastes. The research on environmental samples focused primarily on analyzing the organic constituents at the Maxey Flats waste burial site. Chelating agents and various carboxylic acids were found and were implicated in the movement of radioactive metals. Hydrophobic (nonpolar) organics were also identified. Other environmental methods were included in this review because of the sampling techniques that were specifically designed for radioactive work.

Foreign contacts have also been requested to provide French and English sources on methods for determining organics in radionuclear wastes. The information received thus far indicates that little emphasis has been made in these countries to specifically analyze and report methods for organics in radioactive samples.

The literature surveyed from this search indicates that in spite of the vast amount of work describing methods for the analysis of organic compounds in a variety of sample matrices, very little method development effort has been spent to date on samples containing significant amounts of radioactivity. With a national imperative to accelerate the treatment and disposal of defense wastes, it is expected that this void will be rapidly filled. 


\section{ACRONYMS}

ALARA As low as reasonably achievable

AOAM Advanced Organic Analysis Methods Group

BNL Brookhaven National Laboratory

BSTFA N,O-bis(trimethylsilyl)trifluoroacetamide

BWR boiling-water reactor

DoD Department of Defense

DOE Department of Energy

DPBA diphenylborinic acid

DROLS Department of Defense Research Online System

DSS-1 double-shell slurry-1

DSSF double-shell slumy feed

DTIC Defense Technical Information Center

EDTA ethylenediaminetetraacetic acid

EPA Environmental Protection Agency

FID flame ionization detection

FMPC Feed Materials Production Center

FTIR fourier transform infrared spectrometry

GC

HEDTA N-(2-hydroxyethyl)ethylenediaminetriacetic acid

HEPA high efficiency particulate air (filter)

HPLC high performance liquid chromatography

HSL Hazardous Substance List

LANL Los Alamos National Laboratory

LLW low-level waste

MW molecular weight

NCRW neutralized cladding removal waste

NPH normal paraffin hydrocarbon

NRC Nuclear Regulatory Commission

ORNL Oak Ridge National Laboratory

PCBs polychlorinated biphenyls

PIC paired-ion chromatography

PNL Pacific Nonthwest Laboratory

PT purge and trap (system)

PWR pressurized-water reactor

RCRA Resource Conservation and Recovery Act

SEC size exclusion chromatography

SVOA semivolatile organic analysis

TOC total organic carbon

TPB tetraphenylboron

VOA volatile organic analysis

WHC Westinghouse Hanford Company

WIPP Waste Isolation Pilot Plant 


\section{CONTENTS}

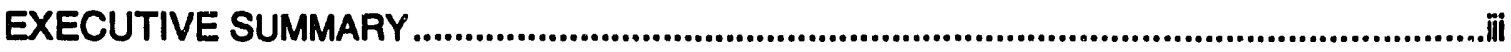

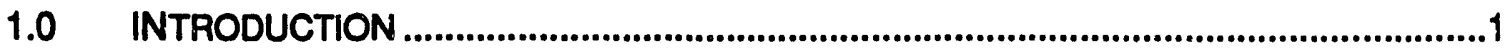

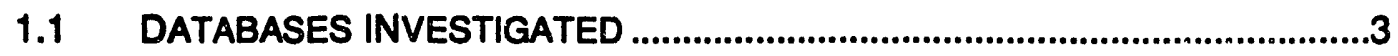

1.1.1 On-Line Computer Databases ...................................................3

1.1.2 Other Databases ......................................................................3

1.2 ANALYTICAL METHODS NOT INCLUDED IN THIS REVIEW.........................4

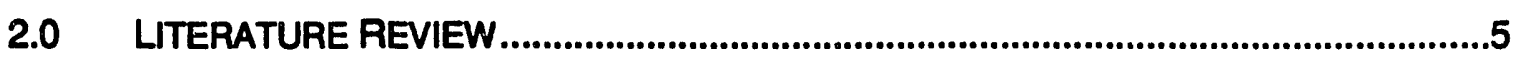

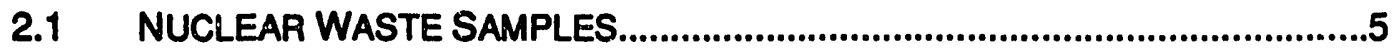

2.1.1 Sampling..............................................................................5

2.1.2 Gas Chromatographic Techniques...........................................11

2.1.3 High Performance Liquid Chromatography................................16

2.1.4 Total Organic Carbon.............................................................17

2.1.5 Other Analytical Techniques ...................................................19

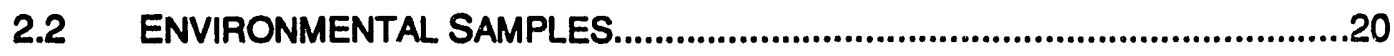

2.2.1 Feed Materials Production Center..............................................20

2.2.2 Maxey Flats..........................................................................21

2.2.3 Sheffield and Bamwell Low-Level Radioactive Waste Disposal Facilities.........................................................................26

2.2.4 Analysis of Tetraphenylboron in Natural Waters......................26

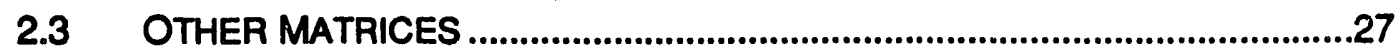

2.3.1 Nuclear Materials ......................................................................27

2.3.2 Laboratory Matrices - Organic Chelates ...................................27

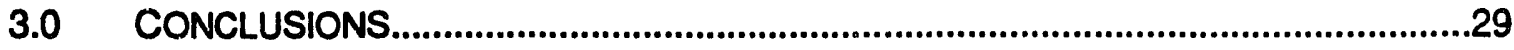




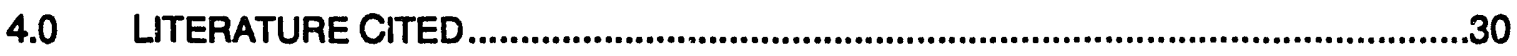

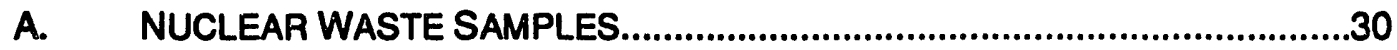

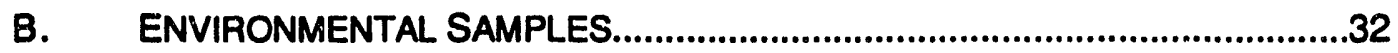

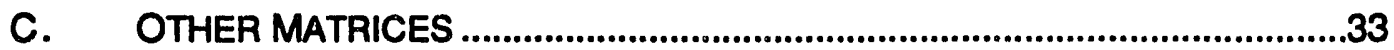

APPENDIX A - REFERENCES TO MIXED WASTE ANALYSIS THAT DO NOT INCLUDE SPECIFIC PROCEDURES

APPENDIX B - CITATIONS FOR ANALYTE TYPES

B.1

APPENDIX C - CITATIONS FOR METHODOLOGY TYPES

C. 1

APPENDIX D - DESCRIPTION OF DATABASE SEARCHES

D.1

APPENDIX E - INFORMATION FROM FOREIGN SOURCES.

E.1 


\section{FIGURES}

$1 \quad$ Liquid Sample Collection System....................................................................7

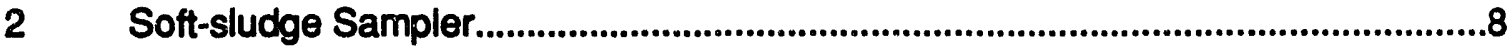

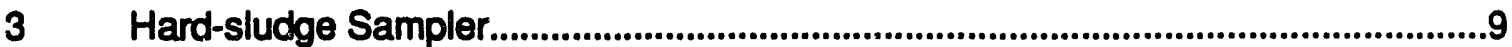

$4 \quad$ Cryogenic Vapor Trap Sampling System..........................................................10

5 Teflon Sampling Head Used in Collecting Volatile Organics..................................14

6 Layout of Volatile Organics Sampling Equipment in and Around a Glove Box.....................................................................................................................15

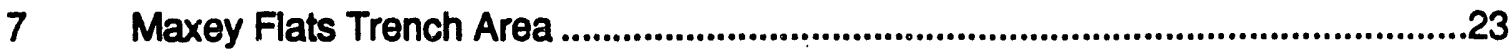

\section{IABLES}

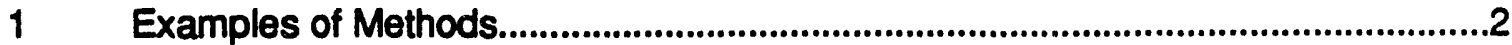

2 Hydrophilic Organic Compounds in Waste Leachates from Maxey Flats .............24

3 Hydrophobic Organic Compounds in Waste Leachates from Maxey Flats ..........25

4 Sources of Wastes Containing Organic Liquids ............................................ A.4

$5 \quad$ Waste Types Containing Organic Liquids....................................................4.4 


\subsection{INTRODUCTION}

Characterization of Hanford wastes as a prerequisite to remediation is accepted as a responsible policy consistent with maintaining a safe and environmentally acceptable condition during cleanup operations. This policy is consistent with recommendations of the Tank Waste Science Panel(a) that "Tank 101-SY be physically and chemically characterized as fully as possible and as expeditiously as safety considerations allow," and that "No remediation steps be taken until there is a better understanding of the chemical and physical phenomena connected with gas generation and release in in Tank 101-SY." There is little doubt that other Hanford remediation activities will focus on characterization prior to cleanup. Regulations, Tri-Party Agreement provisions, and environmental impact statement requirements also require comprehensive knowledge of waste constituents. Hanford is conducting comprehensive programs for the characterization of wastes. In its planning for remediation (WHC-EP-0416), Westinghouse Hanford Company (WHC) has also stressed the need for waste characterization.

Standard methods available for analysis of organic compounds in wastes have been shown to be inadequate for Hanford's needs. Methods that work in high level waste are needed to support the tank characterization effort. EPA methods (e. g., SW 846) are not effective or implementable to many types of samples found at Hanford because of their high radioactive levels, high $\mathrm{pH}$, and high salt contents. The EPA methods were not designed to analyze many chemicals found in high concentration in certain Hanford wastes; such as organic chelators. It has already been found that standard analytical methods have, in some cases, been entirely ineffective for some tank waste samples because of interferences(b). Therefore, it is essential to have at Hanford a comprehensive program for characterization of the organic species in waste tanks. A further discussion of mixed waste analytical problems and concerns is given in Appendix A.

(a) Tank Waste Sciences Panel. Hanford Tank Safety Project. Chemical and Physical Processes in Tank 241-SY-101: A Preliminary Report, T. H. Dunning and E. P. Horwitz, Co-Chairmen. PNL-7595. Pacific Northwest Laboratory, Richland, WA 99352, February, 1991.

(b) For example, see references A15 and A16. 
To develop a sound organic characterization program, Pacific Northwest Laboratory (a) (PNL) has conducted a survey of existing analytical methods that might be applicable to tank wastes. This report is the result of the initial reviews of available organic analytical methods applicable to the analysis of organics in the Hanford tanks. Published methods for analyzing and quantifying organic compounds in mixed wastes are reviewed. Mixed waste refers to waste that contains both radioactivity and hazardous chemicals. The analytical chemistry of mixed wastes is more complex than the analysis of most other substrates, because of health, safety and contamination considerations. To protect workers from undue radiation exposure, and maintain exposure as low as reasonably attainable, much of the sampling, sample preparation, and actual assay must be done from a distance or behind protective barriers. This includes remote sampling and the use of glove boxes or hot cells for sample preparation and shielded instruments for analysis. In addition, measures must be taken where possible to minimize contamination of expensive laboratory instrumentation and facilities, as well as minimize the amounts of waste generated during the procedure. Table 1 lists some of the more useful referencas found in this review. Additionally, Appendixes $B$ and $C$ list references by analyte and method.

IABLE1, Examples of Methods*

\begin{tabular}{|c|c|c|c|}
\hline Matrix & Preparation & Analyte & Beference \\
\hline ORNL Tank Waste & $\begin{array}{l}\text { Sampling } \\
\text { Techniques. } \\
\text { Modified EPA } \\
\text { GC/MS methods. }\end{array}$ & VOA, SVOA & $\mathrm{A} 2, \mathrm{~A} 3, \mathrm{~A} 9, \mathrm{~A} 10$ \\
\hline $\begin{array}{l}\text { DSSF, NCRW, } \\
\text { BWR, PWR }\end{array}$ & $\begin{array}{l}\text { Modified EPA } \\
\text { methods. } \\
\text { Organic acid } \\
\text { derivatization. }\end{array}$ & $\begin{array}{l}\text { VOA; basic, acidic, } \\
\text { and neutral organic } \\
\text { compounds }\end{array}$ & A5-A8 \\
\hline Hanford Tank Waste & $\begin{array}{l}\text { NPH clean up prior } \\
\text { to analysis. GC/MS }\end{array}$ & VOA, SVOA & A15, A16 \\
\hline Simulated Waste & Paired-ion HPLC & Chelators & A21-23 \\
\hline
\end{tabular}

(a) Pacific Northwest Laboratory is operated for the U. S. Department of Energy under Contract DE-AC06-76RLO 1830 by Battelle Memorial Institute. 


\subsection{DATABASES INVESTIGATED}

\subsubsection{On-Line Computer Databases}

To gather information on this subject searches were conducted on various computer databases:

- Chemical Abstracts, 1967 to 1991

- Energy Science and Technology Database, 1974 to August 1991

- Nuclear Science Abstracts, 1948 to 1976

- U.S. Department of Defense Defense Research Online System (DROLS).

The first three databases are available on the DIALOG System, accessed through the PNL Technical Informe romputer Network. DROLS is available through the Defense Technical Information Centar (DTIC).

Initially, an extensive list of keywords was developed to n urrow the search "hits" to a manageable number. This strategy resulted in very few "hits" for most of the trials. The best strategy for recovering useful information was to use very general keywords and then manually search the abstracts for relevant material. Keywords used in the searches included "mixed waste," "radioactive waste", "analytical chemistry," "organic compounds", "analy..." and "organic," etc. A more detailed description of the search is given in Appendix $D$.

\subsubsection{Other Databases}

Another DOE database is emerging as a result of a project funded to PNL by the Office of Technology Development (EM-50), under the DOE Office of Environmental Restoration and Waste Management. This project, "Analytical Management - Methods Compendium Development," is developing a comprehensive manual that catalogues all of the analytical methods used by the DOE community. The manual, "DOE Methods for Evaluating Environmental and Waste Management Samples (DOE Methods)," has been prepared in a draft form for review. The catalogued methods are also being incorporated into a computer database at Los Alamos National Laboratory (LANL). The drtabase was searched by recovering methods from the database at LANL and by searching project files existing at PNL.

A precursor to the DOE Methods Manual was a compilation of Hanford site analytical methods that was assembled as a result of a WHC-funded project. This 
compilation, "Hanford Environmental Analytical Methods Manual," compiled and edited by S.C. Goheen, M. McCulloch, and J. L. Daniel June 1989, exists as a comment draft. This document was manually searched for methods adapted to radioactive wastes.

An additional potential source of information is from foreign sources. The literature surveyed in this report does not include references from foreign sources, although efforts were made as part of the project to establish contacts in France and England that would provide information about the extent of relevant literature in those countries. The initial results of these efforts are given in Appendix $E$.

Additional material was acquired in a survey of the (secondary) references in papers found by the computer searches.

\subsection{ANALYTICAL METHODS NOT INCLUUDED IN THIS REVIEW}

This review is limited to methods designed or modified to analyze organics in mixed waste systems. For many methods dealing with waste samples, particularly in the case of those recovered from the DOE Methods Manual, standard EPA methods were described that contained no modification for the radioactivity contained by the sample. These methods, and other methods where there was no specific provision for, or mention of accommodating radioactive samples, were not included in this review. Methods for analyzing samples with organics that did not contain radioactivity, even if the sample came from a nuclear facility, were also not included in this review.

The subject of organic analysis in mixed waste has not been extensively studied. Most of the analysis of mixed waste involves the analysis of radionuclides. In the preparation of this report, over 400 titles were scanned after recovery by one of the search methods given above. Over 150 citations were physically recovered and are on file in our electronic database. From all these possible applicable documents, less than 75 papers, reports, and presentations were found that fit our search criteria. A. P. Toste, formerly with the Advanced Organic Analysis Methods Group (AOAM) at PNL, had the largest contribution to the database, with eleven references; he performed his analyses under Westinghouse Hanford-funded studies. The present staff of the AOAM had nine references. 


\subsection{LITERATUREREVIEW}

The main body of this review consists of three sections: A) Nuclear Waste Samples; B) Environmental Samples; C) Other Matrices.

\subsection{NUCLEAR WASTE SAMPLES}

This section reviews methods for analyzing organics in mixed waste that is in controlled containment. This includes waste generated by commercial, research, and defense facilities. Mixed waste that has escaped into the environment is covered in the next section.

\subsubsection{Samoling}

The need for protecting workers, facilities, and equipment from undue exposure and maintaining good analytical protocol are factors in determining the sampling technique. In some inster ces, EPA SW-846 methodology is followed (A1). This sampling methodology is workable for storage drums, filter cakes, and other easily accessible matrices. For the sampling of underground mixed waste storage tanks special devices and techniques must be devised. The matrices found within the storege tanks are rarely uniform from top to bottom or from tank to tank.

By sampling and by remote television inspection Griest (1991) determined that tanks at Oak Ridge National Laboratory (ORNL) generally have a liquid phase over sludge phases of various consistencies. Since 1991, ORNL has 33 active low-level liquid waste tanks with capacity ranges of 500 to 15,000 gallons. The total content of the tanks is about 360,000 gallons of liquid, 115,000 gallons of sludge, and $80,000 \mathrm{Cl}$. In 51 inactive tanks at ORNL there is a total of 290,000 gallons of liquid, 39,000 gallons of sludge, and $56,000 \mathrm{Ci}$. A report by Griest (1991) details the devices used in sampling the different layers in the storage tanks at ORNL. The liquid layers were sampled by suction with the sample being collected in a trap jar. A second "safety surge jar" and high efficiency particulate air (HEPA) filters on the vacuum pump were used to minimize release of radiation (Figure 1). Because of the high radiation involved with these samples collecting the volume specified by EPA SW-846, method 3510 (one liter) was judged too hazardous, and sample size was reduced fiftyfold. Samplers were built for the sampling a soft sludge layer and a hard sludge layer. The sludge layers were sampled by coring. The soft sludge sampler consisted with a spring-loaded bottom closure (Figure 2). The 
hard-sludge sampler had a cutting edge for better penetration and a gate valve to retain the sample (Figure 3) $(A 2, A 3)$.

Lucke et al. (1992) described the use of a cryogenic vapor trap for sampling the headspace in mixed waste storage tanks at Hantord. This device trans volatile organics in a glass bexw packed tube that has been chilled with liquid nitrogen (Figure 4). After sampling, the condensate is washed from the glass beads with methanol. The samples are essentially free of radioactivity at this time. Validation studies of this technique are still being performed (A4). 


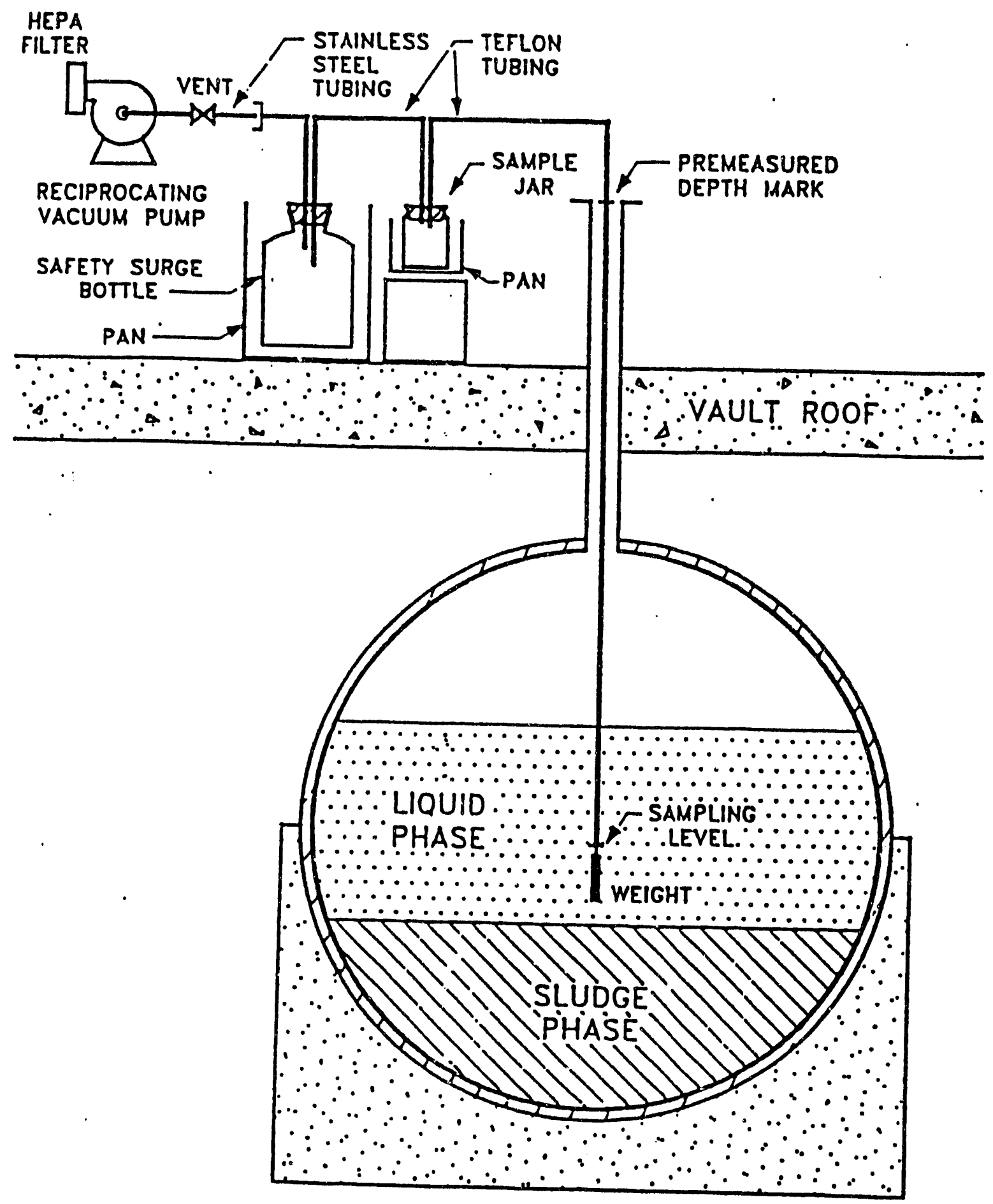

EIGURE1 Liquid Sample Collection System (ref B.2) 


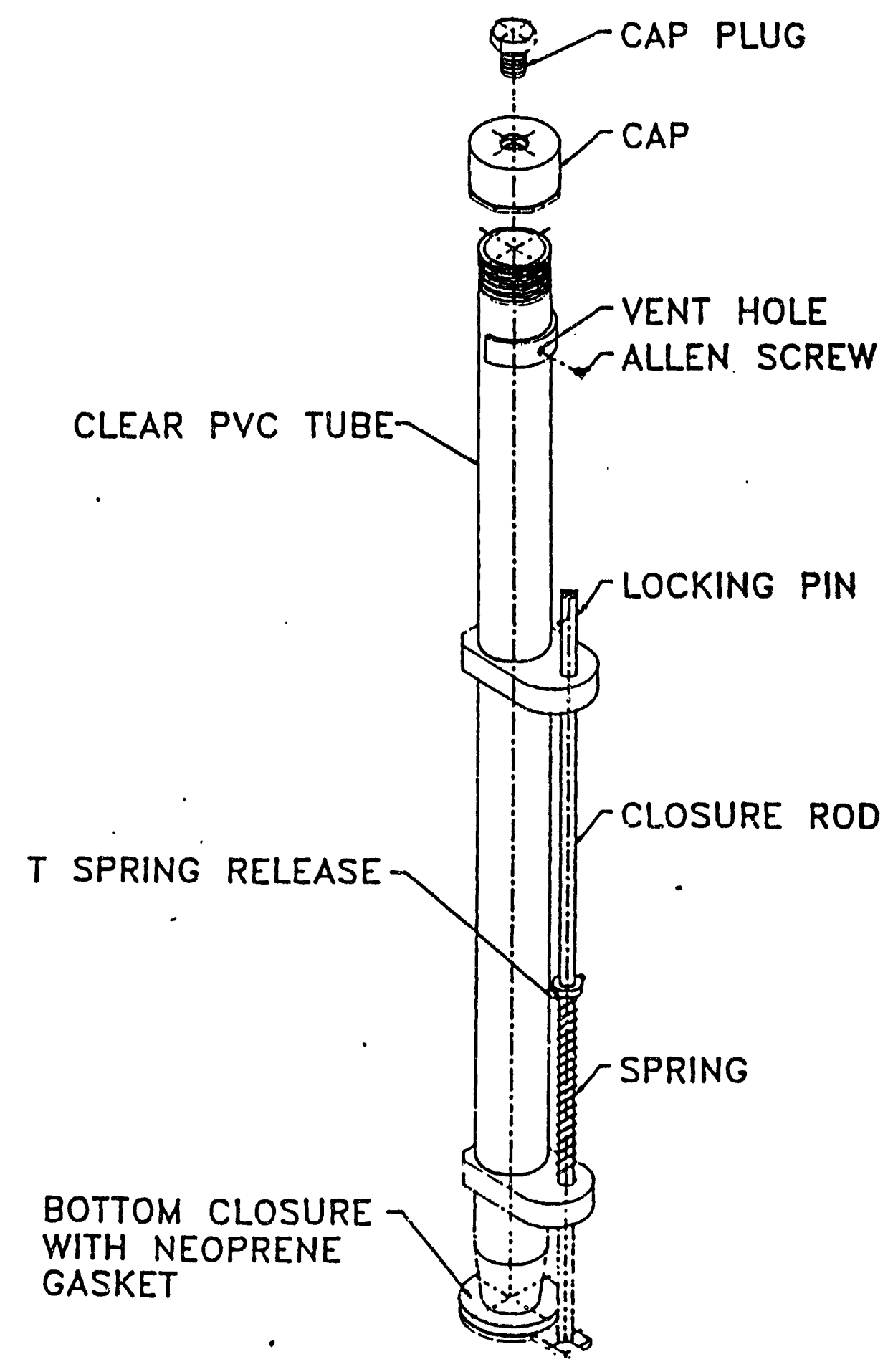

EIGURE2. Soft-sludge Sampler (ref. B.2) 


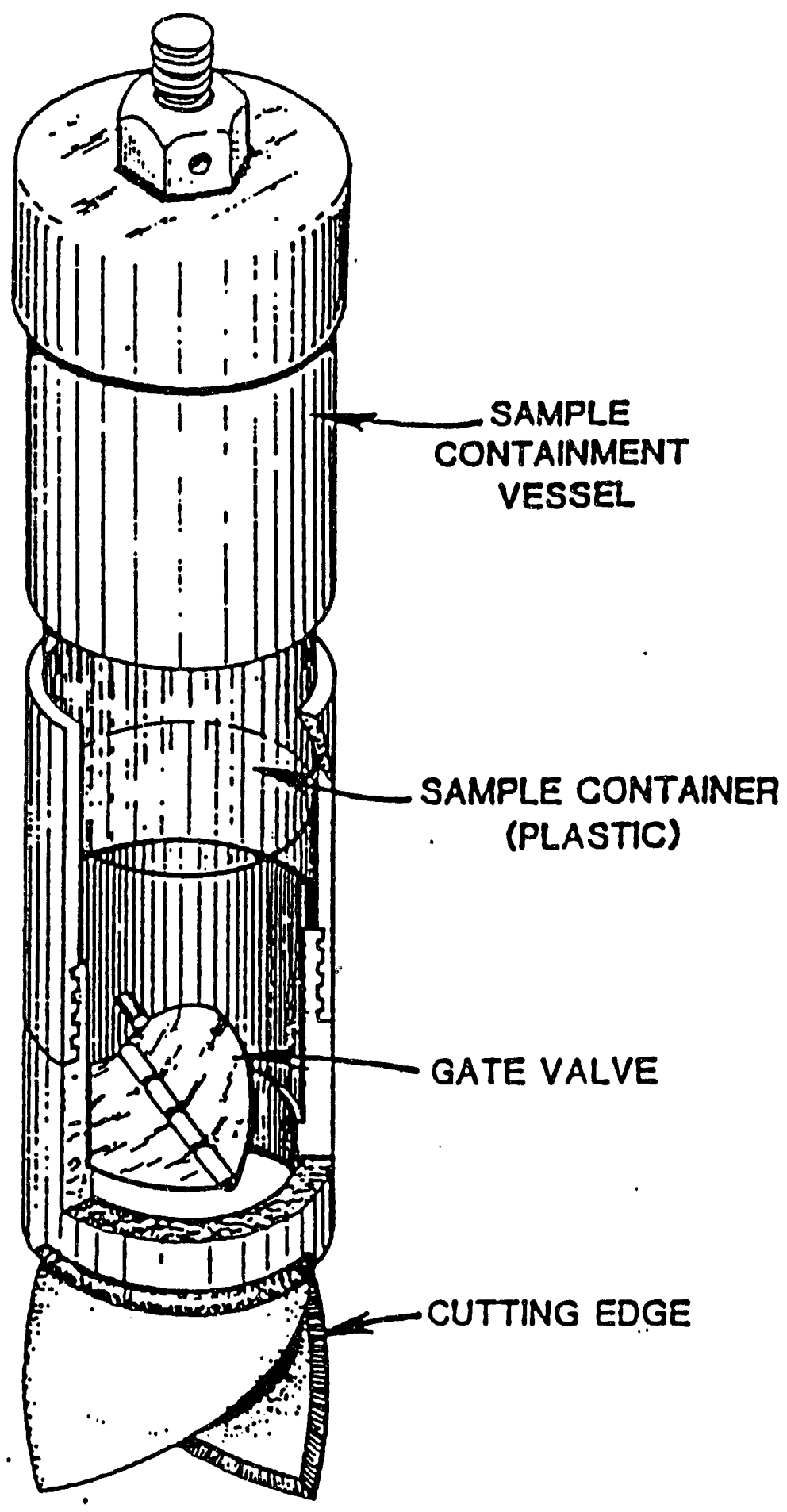

EIGURE3. Hard-sludge Sampler (ref. B.2) 


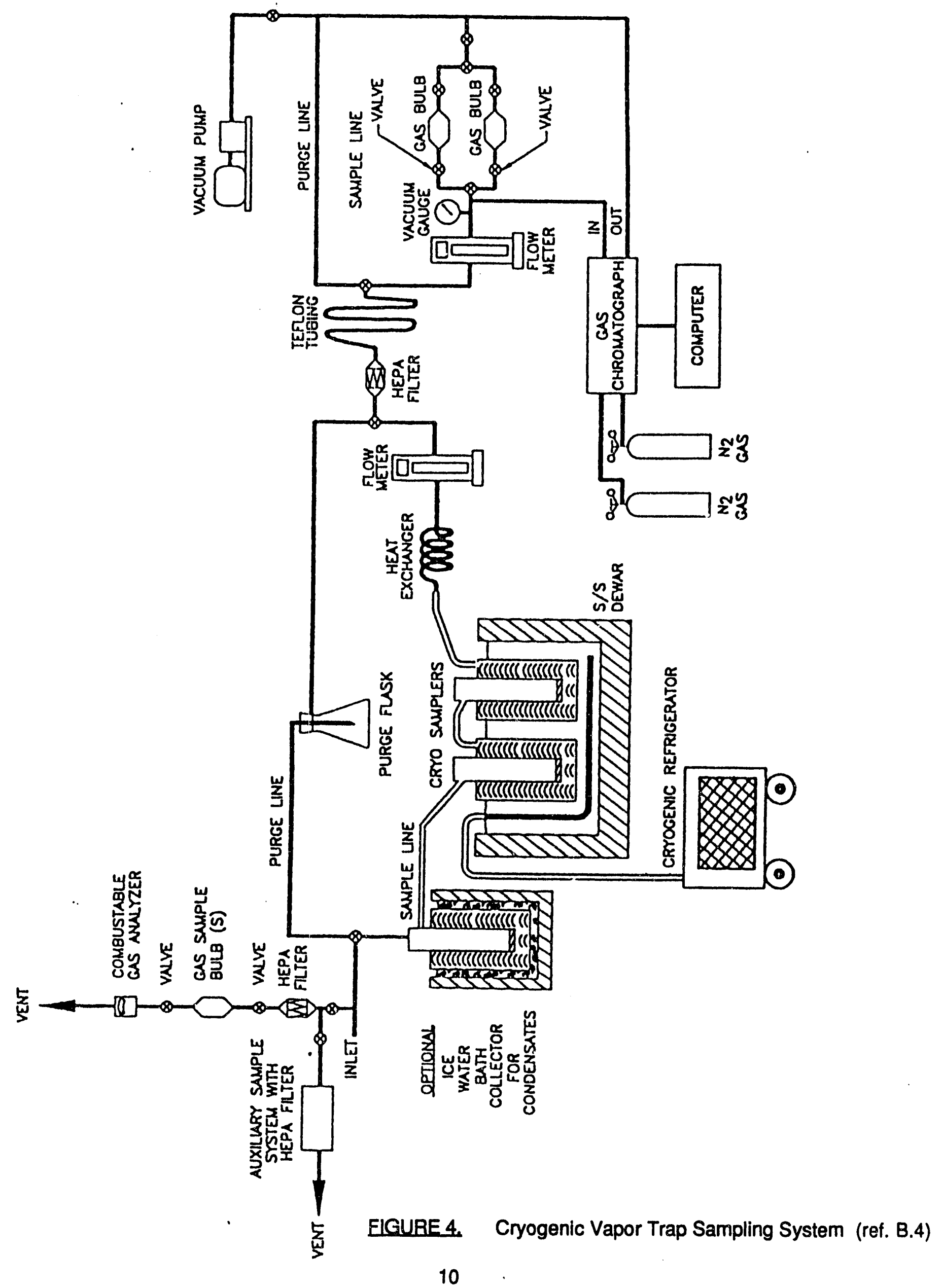




\subsubsection{Gas Chromatographic Techniques}

Gas chromatography $(\mathrm{GC})$ is the predominant method of analysis for organics in nuclear waste. The most extensive publications found in our review were presented by A.P. Toste in a series of papers and reports. The analyses of a variety of organic compounds in a variety of nuclear wastes by GC/flame ionization detection (GC/FID) and GC/mass spectrometry (MS) were described. Matrices analyzed include neutralized cladding removal waste (NCRW), double-shell slurry-1 (DSS-1) waste, double-shell siurry feed (DSSF) waste (A5, A6), pressurized-water reactor (PWR) waste, and boilingwater reactor (BWR) waste $(A 7, A 8)$. Four classes of organics (volatile, basic, acidic, and neutral) were analyzed by EPA methods modified for use in a hot cell or radiation hood. A fifth class of organics, hydrophilic organic acids, including chelating agents, was also analyzed. The chelating agents are not included in EPA's list of priority pollutants, and novel techniques were developed for their analysis.

The high solid content of the NCRW, about $57 \%$ by weight, required separation of the liquid and solid phases by centrifugation and separate analytical approaches for each phase. The volatile organics were captured by a purge and trap (PT) system modified for use in a radiation hood. The PT system was composed of a $23 \mathrm{~cm}$ length of stainless steel 1/8 inch tubing packed with Tenax. A methanol extraction of the solids or the liquid phase directly was purged ontc the sorbent trap. After radiochemical testing showed no radioactivity, the trap was released from the radiation zone and thermally desorbed by PT-GC/MS. A Tekmar Model LSC-?. PT system interfaced with a GC/MS was used to thermally desorb the analytes from the Tenax.

The solvent-extractable organics were recovered from the solids by soxhlet extraction using EPA Method 8270 modified for use in radiation hood. A spike of dpyridine, d-phenol, $d$-naphthalene, and d-phenanthrene was added to serve as a composite intemal standard and to determine extraction efficiencies. The basic and neutral extractables were recovered first, because the $\mathrm{pH}$ of the NCRW was basic. The $\mathrm{pH}$ of the solids was then adjusted to $\leq 2$ with concontrated nitric acid, and the solids were extracted again to recover the acid extractables.

The solvent-extractable organics in the centrifuged liquid were recovered using liquid-liquid extraction method from EPA 625, modified for use in a hot cell. The same standards as above were added. The liquid was extracted three times with dichloromethane at its natural pH (basic) to recover the basic and neutral extractables. 
The liquid was then acidified with concentrated nitric acid and extracted to recover the acidic extractables. No radiation was detected in these extracts, which were removed from the radiation zone. The extracts were concentrated on a Kuderna-Danish apparatus and were analyzed by GC/FID and GC/MS.

The fifth class of organics, the hydrophilic organics, was worked up in a radiation hood using a methylation-GC/MS procedure. An acid dissolution of the NCRW sludge was concentrated to a residue under nitrogen stream at $50^{\circ} \mathrm{C}$. The residue was methylated for 40 minutes with $\mathrm{BF}_{3} /$ methanol. The methyl esters were taken up in chloroform and analyzed by GC/FID and GC/MS.

The DSS-1 and DSSF waste were handled in a similar manner. The liquid-liquid extraction, however, was done by a significantly altered EPA method 3520 using a 250$\mathrm{mL}$ flat bottom flask equipped with a magnetic stir bar and a water-cooled condenser in a hot cell $(A 5, A 6)$.

The PWR waste was an evaporator concentrate of a boric acid waste. The most abundant radionuclides were ${ }^{137} \mathrm{Cs}$ and ${ }^{134} \mathrm{Cs}$. The BWR waste was an evaporator concentrate of liquid waste produced during the regeneration of ion-exchange resins used to purify a reactor's process water. The most abundant radionuclides were ${ }^{60} \mathrm{Co},{ }^{137} \mathrm{Cs}$, ${ }^{54} \mathrm{Mn}$, and ${ }^{134} \mathrm{Cs}$. The waste was extracted three times with chloroform, yielding the hydrophobic extractables. The extracted waste was then evaporated under a $\mathrm{N}_{2}$ stream at $50^{\circ} \mathrm{C}$, and the resulting residue was methylated for 20 minutes at $100^{\circ} \mathrm{C}$ with $B F_{3} /$ methanol. The methyl esters were taken up in chloroform and analyzed by GC/FID and GC/MS (A7).

Griest et al. (1980) adapted SW-846 methods to analyze organics in highly radioactive mixed waste (A9). These modifications allowed for the use of EPA methods 5030 and 3510-3550 for sample preparation and methods 8240 and 8270 for volatile organic analysis (VOA) and semi-volatile organic analysis (SVOA), respectively. The modifications involved carrying out specific components of these methods within radiation hoods, glove boxes, and hot cells. The VOA was carried out with a purge and trap device placed in a glove box and linked to a GC/MS (Figures $5 \& 6$ ). The SVOA samples were extracted by mechanically tumbling vials in a hot cell. Standard SVOA extraction methods such as separatory funnel liquid-liquid extraction were judged to have a higher spill potential. After extraction the SVOA samples were first screened by GC/FID and then, if warranted, were tested by GC/MS. These analyses were tested on 
aqueous liquids and sludges. Recovery of surrogates and a discussion of EPA QC Acceptance Limits are given in this report and two other papers prepared by Tomkins and co-workers (AB, A10).

The presence of chelators in nuclear waste has been of particular concern. Chelators, and their degradation fragments, must be derivatized prior to analysis by GC. Because the chelators (e.g., ethylenediaminetetraacetic acid (EDTA) and N-(2hydroxyethyl)ethylenediaminetriacetic acid (HEDTA)) have more than one carboxylic acid functional group there is a potential for a varying degree of derivatization. Conditions must be monitored carefully so that complete derivatization takes place. Methylation of the carboxylic acid groups with $\mathrm{BF}_{3}$ /methanol is the method of choice $(\mathrm{A11}, \mathrm{A} 12)$. Other derivatization methods have been evaluated. These include methylation with diazomethane, butylation with butanol/HCl, and silylation with BSTFA (A13). Chelator degradation and rearrangement products have been determined by GC linked with fourier transform infrared spectrometry (FTIR). This technique demonstrated the formation of lactams by some of the chelator fragments present in some of the mixed waste samples (A11). GC linked with high-resolution mass spectrometry has shown the presence of nitrosoamine-type compounds. This implies an interaction between chelators and the inorganic components found in mixed waste (A12).

Tomkins and Caton (1982) described methods for the analysis of EPA priority pollutants in ORNL tank sludges by GC and HPLC. The HPLC methods will be discussed in a separate subsection. GC with electron capture detection was used to analyze for EPA organochlorine pesticides. Solid phase extraction columns, manifolds, pumps, and pressure controllers were obtained from J.T. Baker Co. The clean-up procedure described was designed such that one manifold was always used for collecting organics from radioactive aqueous samples, while the other was always used for eluting the analytes from the loaded columns that had been washed free of radioactivity. The radioactivity, mainly ${ }^{137} \mathrm{Cs}$, was removed by passing the sample through octadecyl solid-phase extraction columns with water. The analytes were then eluted with hexane and quantitated as per EPA method 608 (A14). 


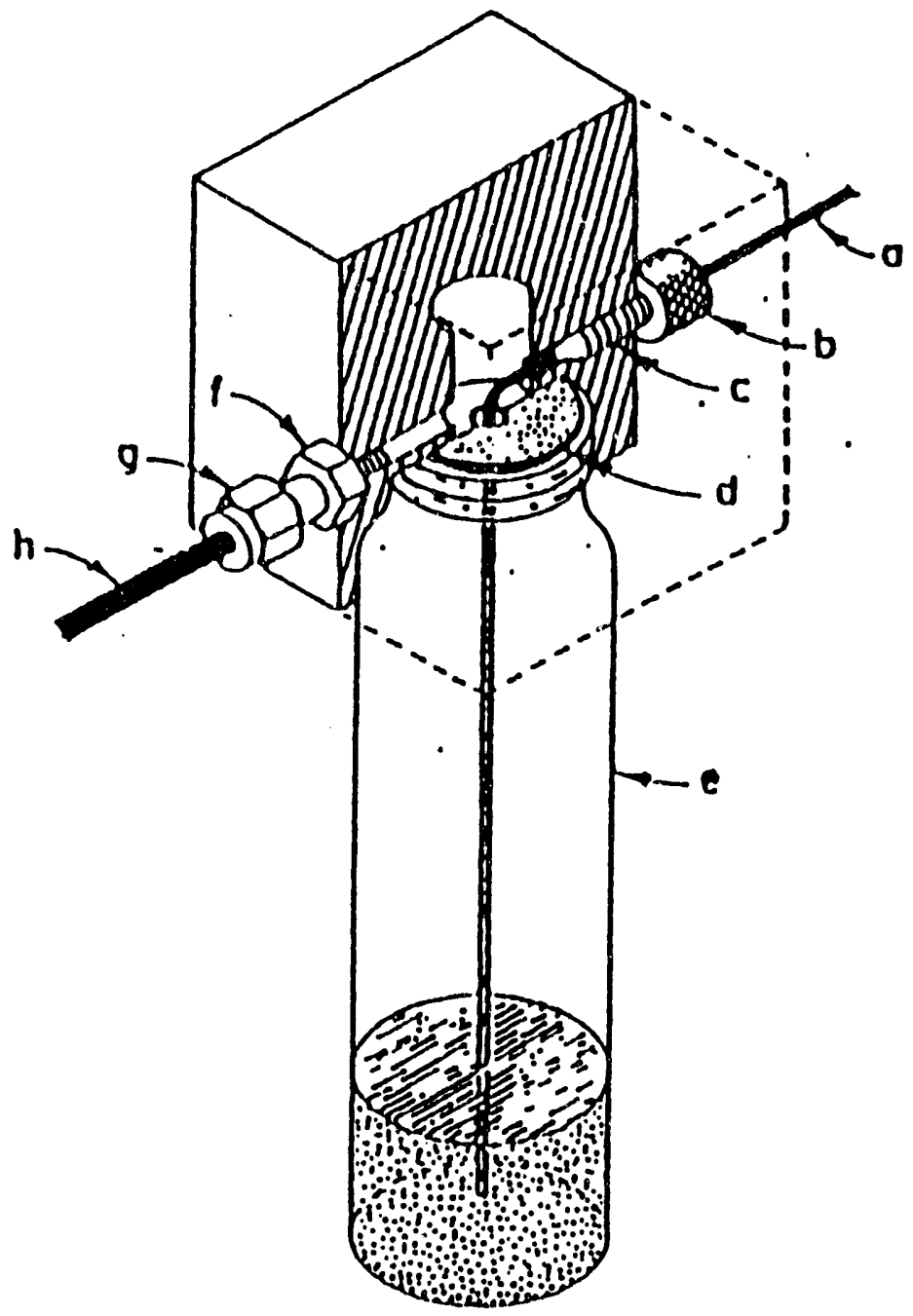

EIGURE 5. Teflon Sampling Head Used in Collecting Volatile Organics: (a) Capillary Teflon tubing $1 / 16$ in. O.D. $\times 0.3 \mathrm{~mm}$ I.D., (b) finger tight fitting, (c) 10/32 screw port, (d) Tefion faced rubber septum with hole, (e) $40 \mathrm{~mL}$ VOA vial, (f) $1 / 8$ to $1 / 8$ in. union, (g) 1/8 in. nut, and (h) 1/8 in O.D. Teflon Tubing (ref. B.18) 

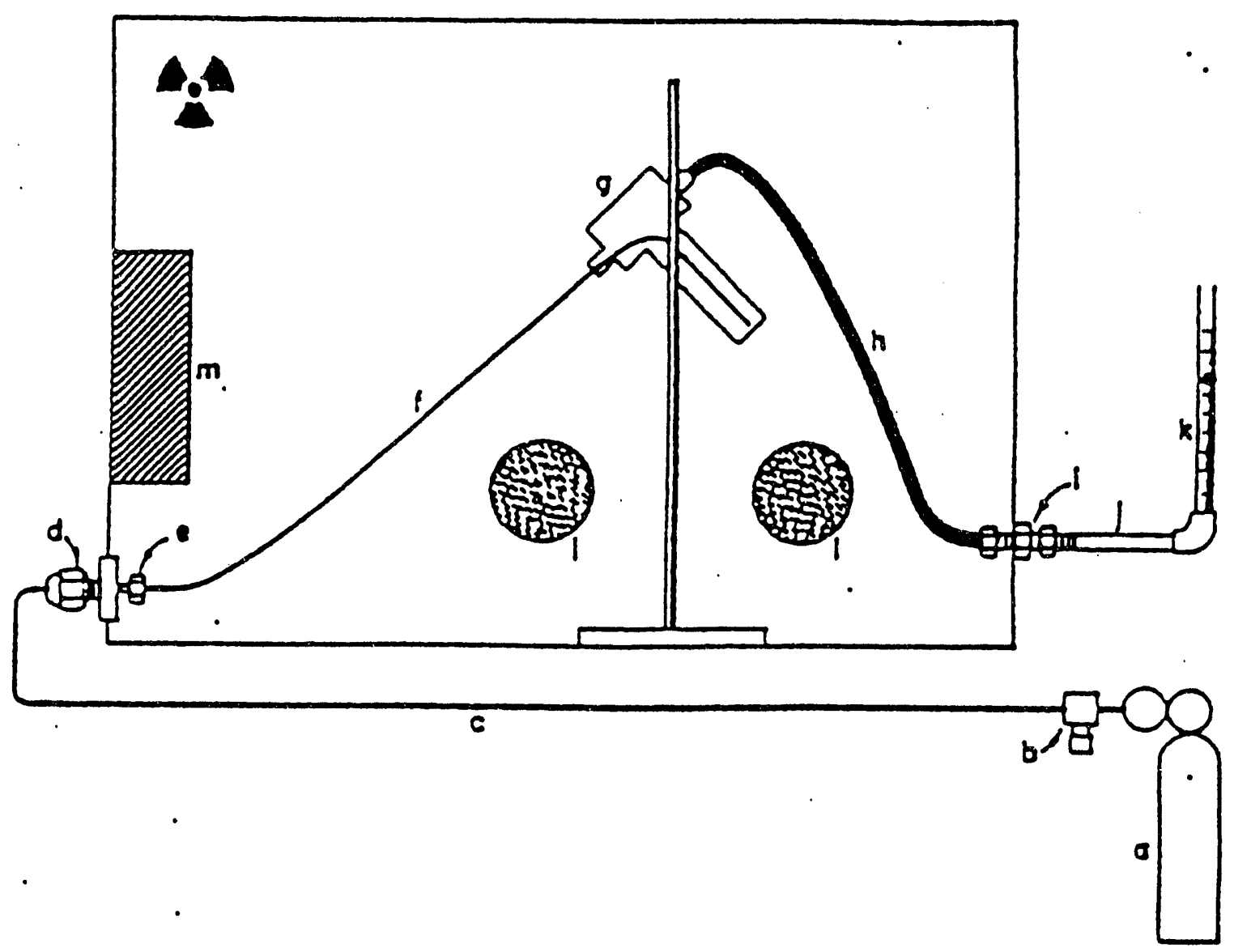

EIGURE6. Layout of Volatile Organics Sampling Equipment in and Around a Glove Box: (a) nitrogen cylinder, (b) needle valve, (c) 1/8 in. O.D. copper line, (d) and $(\theta) 1 / 8$ in. to $1 / 16$ in. bulkhead, $(f)$ capillary tubing $1 / 16$ in. O.D. $x$ $0.3 \mathrm{~mm}$ I.D., (g) Teflon sampling head (see Figure 5), (h) 1/8 in. O.D. Tefion line, (i) $1 / 8$ in to $1 / 8$ in. bulkhead, (j) EPA Method 624 three stage trap for volatiles, $(k)$ flow rotometer, (l) glove ports, and $(m)$ bag-in/bag-out port. (ref. B.18) 
E.W. Hoppe et al. (1992) presented the development and validation of a method for the removal of normal paraffin hydrocarbons (NPHs) from tank waste prior the the analysis of semi-volatile and volatile organic analytes by GC/MS. NPHs are straight chain hydrocarbons, typically $C_{11}$ to $C_{15}$. These compounds are present in the tanks as a result of process waste disposal. They are also used as a hydrostatic fluid for some of the tank sampling procedures, which can result in severe sample contamination. NPH can foul purge and trap devices and interfere with GC/MS procedures. To remove interfering NPH from waste samples, disposable packed cartridges were used. A silica gel cartridge was used to remove the NPHs for the SVOA, and a $C_{18}$ cartridge was used for the VOA (A15, A16).

A Pacific Northwest Laboratory procedure describes the clean up of single-shell tank samples for analysis or screening by GC/FID or GC/MS. This procedure is for extracting nonvolatiles and semivolatiles from solids, including waste samples from singleshell tanks. Sonication is used to ensure intimate contact of the sample matrix with the extracting solvent, usually dichloromethane. After sonication the sample is filtered The clean up has an optional gel permeation chromatography step (A17).

Method PVO30R in the new DOE methods compendium describes the use of purge and trap for VOA in water-miscible liquids, solids, wastes and sediments. Method OG015R in the methods compendium describes direct aqueous injection gas chromatography. This method determines major non-halogenated volatile organic compounds in radioactive aqueous liquids. It is designed to supplement purge and trap analysis by providing data on highly polar, water-soluble organic compounds that are not determined very well by purge and trap (A18, A19).

Spall and Sandoval (1992) described the modification of EPA SW-846 Purge and Trap Methods 5060 and 8240 for use with radioactive samples. A glove box was used and the effects on accuracy, precision, and recovery were measured (A20).

\subsubsection{Hiah Performance Liquid Chromatography}

High performance liquid chromatography (HPLC) analysis of nuclear wastes is used predominantly to analyze for chelators. The advantages of HPLC analysis over $\mathrm{GC}$ is that the chelators need not be derivatized and clean up need not remove all the non-volatile inorganics, as long as they are soluble in the mobile phase. Typically chelators are analyzed by paired-ion chromatography $(P I C)$ on $C_{18}$ columns. The PIC reagents are typically dodecyltrimethylammonium bromide (A21, A22) or 
tetrabutylammonium hydroxide (A23). Detection is usually by UV absorbance of the iron(III) (A24) or copper(II) (A23, A21,A22) complexes. The complexed metal may be added to the mobile phase or the sample.

Most of the HPLC work done so far is on "simulated" waste; a mixture created in the laboratory to resemble mixed waste found in nuclear waste storage tanks. Using simulated waste the interrelationship of chelators with other waste constituents can be studied (A21). The degrading effects of uranium on EDTA in simulated waste has been monitored by HPLC (A23).

Some studies have been done using different chromatographic stationary phases and eliminating the reagents associated with PIC for the analysis of chelators. Eliminating the PIC reagents would make HPLC amenable to detection by mass spectrometry. Because chelators are polar organic compounds they are not well retained on $C_{18}$ columns without the PIC reagent. Thus, more polar stationary phases have been studied; these include anion exchange, anion exclusion, amino, $C_{2}$, diol, and cyano (A23, A24). Amon et al. (1992) found that the resolution of EDTA and HEDTA was greatest in amino > anion exclusion $\geq$ cyano > diol column. They also found that the chromatography on these columns was not as robust as paired-ion chromatography. Resolution and capacity decreased with repetitive injections. (a)

HPLC/Thermospray mass spectrometry using a $\mathrm{C}_{2}$-bonded column was used to exarrine the free acids and copper(II) complexes of EDTA, HEDTA, and citric acid. Particle beam mass spectrometry was also attempted, but no useful data could be obtained because of extensive compound fragmentation (A26, A27).

In HPLC work not related to chelators, Tomkins and Caton were successful in analyzing ORNL mixed waste tank sludges for EPA priority polyaromatic hydrocarbons by HPLC after solid phase extraction on octadecyl columns as described in the Gas Chromatographic Techniques section. This method was not successful for the analysis of EPA priority phenols (A14).

\subsubsection{Iotal Organic Carbon}

Besides GC and HPLC the most common analytical technique applied to nuclear waste is total organic carbon (TOC). With TOC the researcher can determine what

(a) Amon, L. M., S. A. Clauss, J. A. Campbell, and S. C. Goheen. 1992. "HPLC Separations of EDTA from HEDTA." submitted to J. of Chrom. Reference (A25). 
percentage the identified organic compounds comprise of the total organic content. TOC is typically measured using a carbon analyzer. This instrument converts organic carbon to carbon dioxide by either catalytic combustion or wet chemical oxidation. The carbon dioxide can then be m:Jasured by an infrared detector (A28). None of the papers or reports found in this review gives a good overview of the TOC method as related to the analysis of radioactive samples. There is little to suggest that the methods differ substantially from SW-846 Method 9060.

Toste et al. wnre able to account for $94.9 \%$ of the TOC in NCRW by GC/FID and GC/MS analysis. However they were only able to account for $1.2 \%$ of the TOC in DSS-1 waste. Two t 1 eories where advanced to explain this low accounting. First, in a highly ionic matrix, such as that found in DSS-1 waste, organics may partition into a third phase. Since only the extraction solvent phase was analyzed, much of the organic could have been overlooked. Second, the missing organics may be due to classes of organics not amenable to the analytical procedure that was used. Tomkins and co-workers suggested that these compounds could be low molecular weight (MW) organic acids (e.g., oxalic acid) or other polar organics, or conversely the missing organics could be high molecular weight, or polymeric, species. After methylation low MW organic acids could be lost to evaporation in subsequent solvent reduction steps. Other low MW polar species may not methylate and would remain unanalyzable by GC. Polymers are occasionally used in nuclear operations, such as the flocculating agents (e.g. polyacrylamide). Other polymers may be formed from the chemistry occurring within the mixed waste matrix. These polymers would not be sufficiently volatile for GC analysis (A5).

Griest et al. were able to determine that compounds identified in their GC/MS analysis of aqueous liquid samples accounted for less than $20 \%$ of the organics in a inajority of samples. In sludges the TOC accounting was even worse, with the identified components accounting for less than $5 \%$ of the organics. In agreement with Toste's work (A5), Griest suggested that the unaccounted organics could be highly polar, water-soluble organics stemming from the degradation of chelators, extractants, and other compounds found in mixed waste (A9).

Another TOC technique is described in a PNL method. Instead of using an infrared detector, the cartonn dioxide produced by combustion is titrated as carbonic acid and determined by coulometry. This method is applicable to radioactive samples in liquid (A29). 


\subsubsection{Other Analytical Techniques}

GC is the predominate method used in the analysis of organics in nuclear mixed waste. There are, however, a few other techniques, some old and some new that have been used for the analysis of this matrix.

The Waste Immobilization Technology Group at ORNL (Mrochek and co-workers 1986), has formulated grout mixtures to immobilize a mixed, organic, inorganic biodenitrified waste. To monitor the leaching of phenols from this grout the group used a colorimetric assay. The colorimetric determination of total phenolics is based on the reaction of the phenolic material with 4-aminoantipyrine (4-AAP) in the presence of potassium ferricyanide. A reddish-brown colored antipyrine dye is formed. This method determines phenol, ortho- and meta-phenols, and some para-substituted phenols. is this technique Mrochek and co-workers were able to determine that grouts with wigher sodium silicate content were better at resisted leaching of phenolic compounds. They also determined that addition of bentonite clay had little effect on the leachability of phenolic compounds (A30).

Spall et al. (1992) have used supercritical carbon dioxide to extract and quantify 64 EPA semi-volatile compounds in solid samples, soils, and waste-water sludge. The supercritical carbon dioxide extracted compounds that were then cryofocused on the head of a capillary GC. Analysis was by GC/FID without any further sample manipulation. Recovery efficiency was studied and varied from 85 to $100 \%$ (A31).

Chelators and chelator fragments have been examined by electrospray mass spectrometry and thermospray mass spectrometry. Both techniques provided different but useful spectra. The primary ion in electrospray MS was $(M-H)^{-}$. The primary ions in thermospray MS were $(M+H)$ and $(M+18)$. Some of the species examined were ethylenediaminetriacetic acid (ED3A), citric acid, iminodiacetic acid (IDA), and N-(2hydroxyethyl)iminodiacetic acid (HEIDA) (A27).

A computer simulation study examined the relationship of chelators to the solubilities of important actinides (plutonium, americium, and neptunium). This type of study provides useful information about the solubility of actinides in the presence of chelators without the cost associated with actual laboratory analysis. Predictions were made using an aqueous composition typical of a leached concrete pore water and by equilibration with the most likely actinide mineral phase. The effect of redox, pH, and concentration of the EDTA, citrate, and acetate was evaluated. The solubility of plutonium 
was increased by the presence of EDTA except at extreme alkaline $\mathrm{pH}$ with reducing conditions. Citrate and acetate had little effect. The solubilities of americium and neptunium were increased by the presence of EDTA and citrate (A32).

\subsection{Environmental Samples}

The techniques for the analyzing of organics in mixed wastes that have been introduced to the environment do not differ greatly from the analysis of organics in stored nuclear waste. Many of the techniques discussed in the previous section could be applied to soil and groundwater samples. Gas chromatography was again the analytical technique most often cited.

There are very few published procedures for environmental analysis that are specific for mixed waste. Only 15 papers on the subject were recovered from the search efforts. Seven of these papers were by A.P Toste and L. J. Kirby, reporting on a series of analyses at the Maxey Flats site in Kentucky. These papers described the migration of mixed waste in soil and groundwater and how chelators aided this migration. Most of the other papers in this section deal with sampling and site description, but standard EPA methods were used for analysis. Goode (1986) has pointed out that environmental sampling must be well planned. The preliminary sampling plan must allow workers to assess:

- the extent of migration of the hazardous chemical constituents

- the scope of the comprehensive sampling plan

- problems before designing the comprehensive sampling plan

- the optimal sampling sites (B1).

In view of the limited references found in the literature on environmental analysis of mixed waste, this section is organized according to the environmental sites studied rather by analytical technique.

\subsubsection{Feed Materials Production Center}

A report on the characterization of the Feed Materials Production Center (FMPC) site in Ferndale, Ohio, is a good case study of environmental sampling. FMPC was responsible for the production of high purity uranium metal. The site's waste facilities consists of six waste pits, four concrete silos, two fly-ash disposal sites, a burn pit, the clear well, sanitary landfill, and two lime sludge ponds. Known organic wastes on the site 
are dichloromethane, perchloroethylene, 1,1,1-trichloroethane, waste oil, and polychlorinated biphenyls (PCBs). Radionuclides on the site include uranium, thorium, and daughters of each. There are also plutonium and neptunium from processing recycled compounds. A sampling grid was constructed by a surveyor at 100 foot intervals. Smaller grids were established by field personnel. All the grid nodes were flagged and assigned a coordinate. Samples were taken from selected coordinates. Dry samples were taken with a 3-inch hollow stem auger. Samples were collected at depth intervals of 2 feet until a site geologist determined that a natural clay barrier had been reached. Wet samples were collected with a rod and piston sampler. All but three samples were tested by Weston Analytics laboratory in Lionville, Pennsylvania. Three samples exceeded Weston's NRC criteria of $10 \mathrm{nCl} / \mathrm{g}$ and were analyzed by Thermo Analytical, Inc. The samples were analyzed for Resource and Conservation Recovery Act (RCRA) characteristics, Hazardous Substance List (HSL) inorganics, HSL organics, HSL organics with a library search for non-HSL constituents, Appendix IX constituents, indicators and anions. All of the testing was done by EPA SW-846, September, 1986 methods. A variety of organic species was found at this site. PCBs, including aroclors 1242, 1248, 1254, and 1260 were consistently found throughout the site. The PCB concentrations ranged from just detectable to 10 parts per million. Polyaromatic hydrocarbons were also found throughout the site. These included anthracene, fluorene, pyrene, and many others. Other species found included acetone, methyl and ethyl parathion, chlordane, DDT, bis(2ethylhexyl)phthalate, other phthalates, chloroform, tetrachloroethene, and xylenes (B2).

\subsubsection{Maxey Flats}

Many of the publications on environmental fate of mixed waste came from research at Maxey Flats, Kentucky. The goal of these experiments was to assess the role of organic species in the migration of radionuclides.

Maxey Flats is one of several commercial shallow-land burial sites located in the eastern United States where rainfall is high compared to burial sites in the arid west. Infiltration of surface water into waste trenches has led to seepage of contaminated groundwater. At Maxey Flats, five section-experimental trenches were installed adjacent to selected waste trenches. The experimental trench sections were spaced progressively farther from the waste trench (from $4 \mathrm{~m}$ to $7 \mathrm{~m}$ ) (Figure 7). Groundwater was sampled during and after construction of the experimental trenches from sumps placed in each section. Nonradioactive tracers were added to the trench to monitor groundwater movement. Pentafluorobenzoic acid was added to the cap of one waste trench section to 
monitor whether surface water seeps into the trench. A series of inert atmosphere wells were drilled around the experimental trench. The inert atmosphere wells were purged with argon between periodic samplings. The inert atmosphere wells were used as sampling devices that would maintain the anoxic conditions of the damp soil. Groundwater samples from waste trenches, experimental trenches, and inert atmosphere wells were taken periodically using peristaltic pumps. The samples were stored under argon at $4^{\circ} \mathrm{C}$ until analysis.

Steric exclusion chromatography (SEC) was used to fractionate the water samples prior to analysis by GC and GC/MS. A specific volume of sample $(25 \mathrm{~mL}$ to $50 \mathrm{~mL}$ ) was evaporated to near dryness and filtered. The sample was loaded onto a Sephadex G-15 column and eluted with Milli-Q@ water. The column effluent was monitored at $254 \mathrm{~nm}$ and collected with a fraction collector. The fractions were extracted with chloroform. These chloroform extracts yielded the hydrophobic extractables. Each extracted fraction was then evaporated under a nitrogen stream and the resulting residue was methylated for 40 minutes at $100^{\circ} \mathrm{C}$ with $\mathrm{BF}_{3} /$ methanol. The methyl esters were taken up in chloroform and analyzed by GC/FID and GC/MS.

A number of of organic species were found in the samples. They are listed in Tables 2 and 3 . The most consistently identified organic compound was the chelator EDTA (B3-B10). 


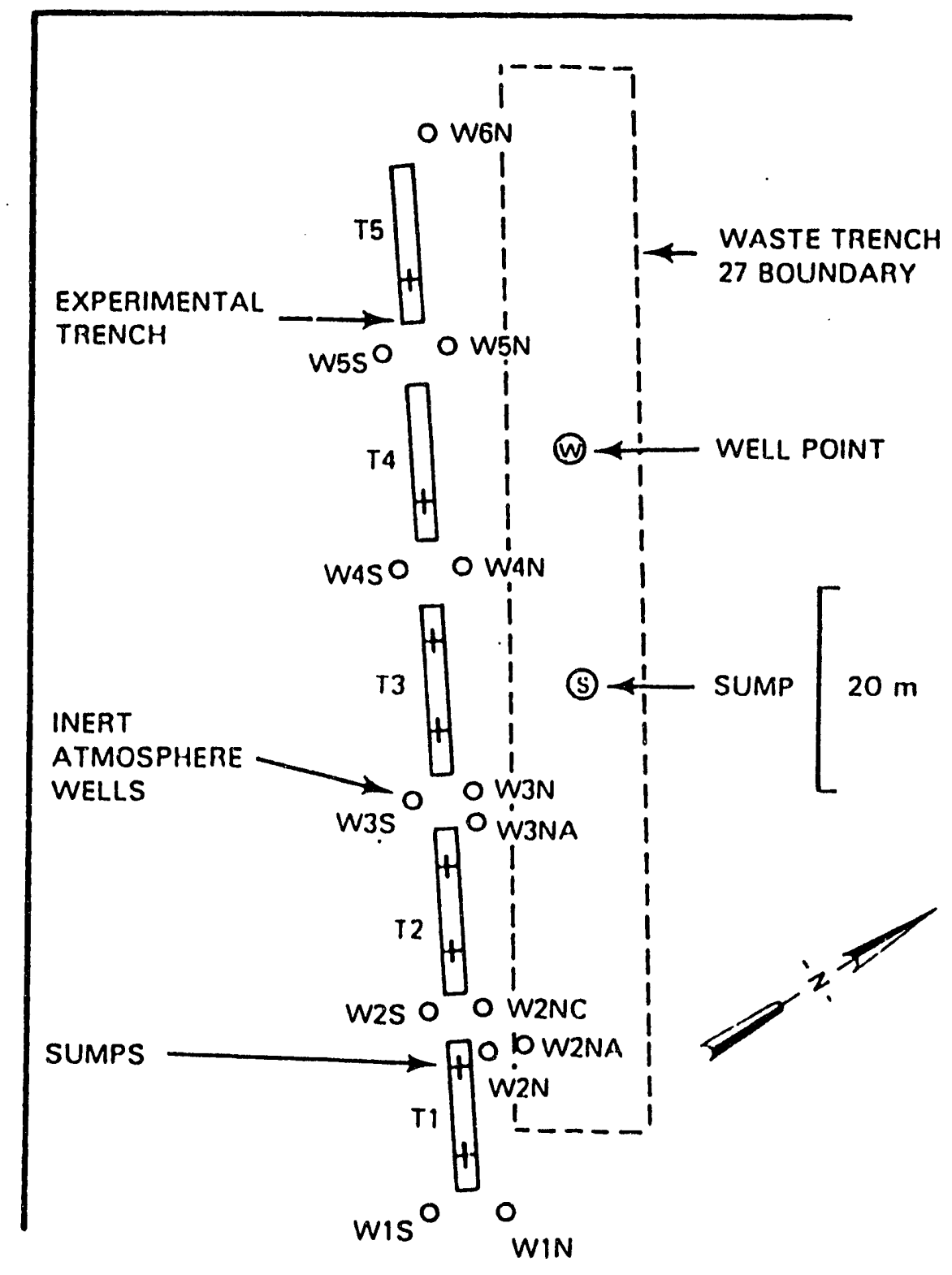

EIGURE 7. Maxey Flats Trench Area. These Facilities Allow Concurrent Sampling of the Experimental Tranch, Inert Atmosphere Wells, and the Adjoining Waste Trench for Groundwater Migration and Chemical Species Studies. 


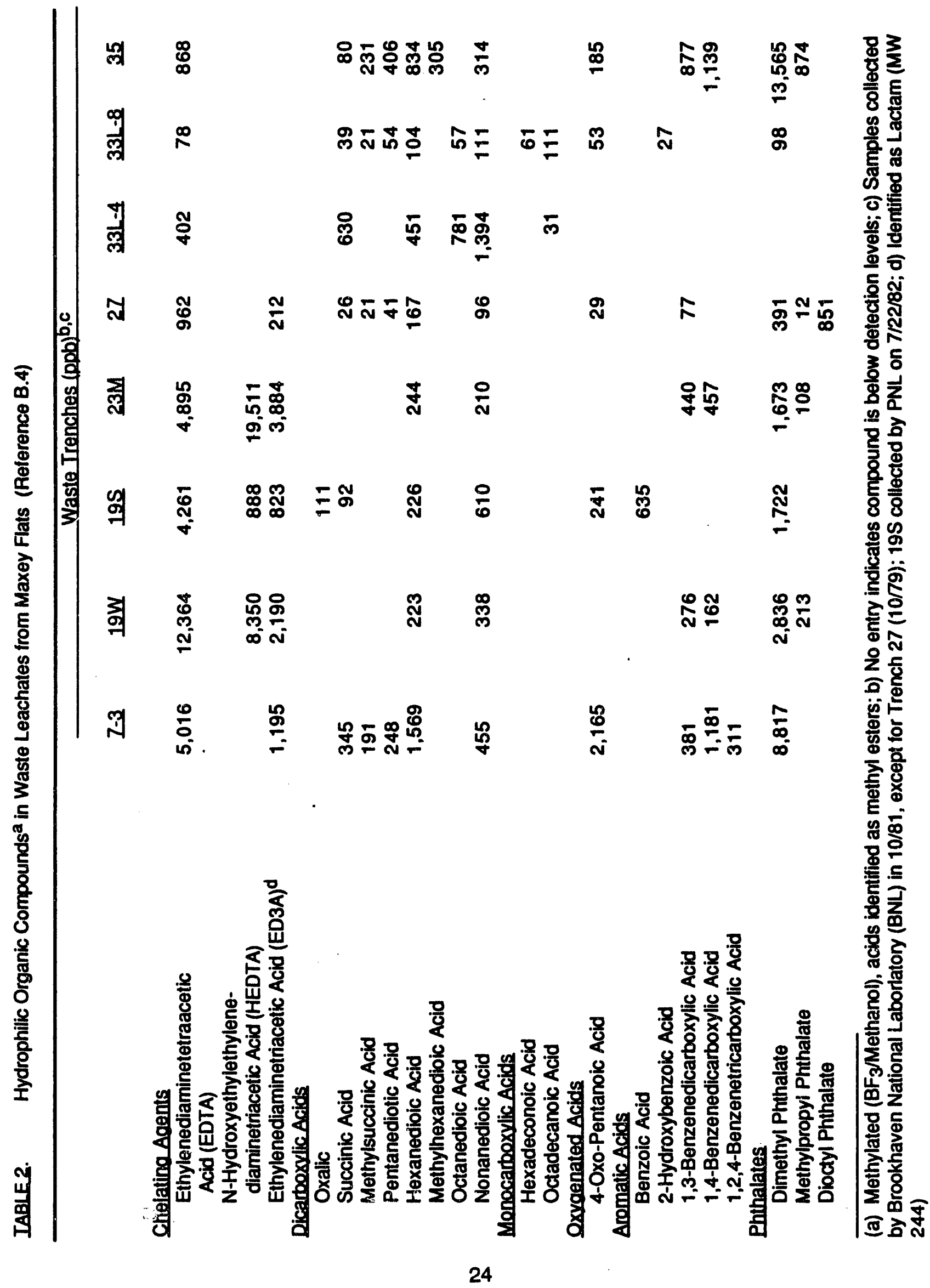




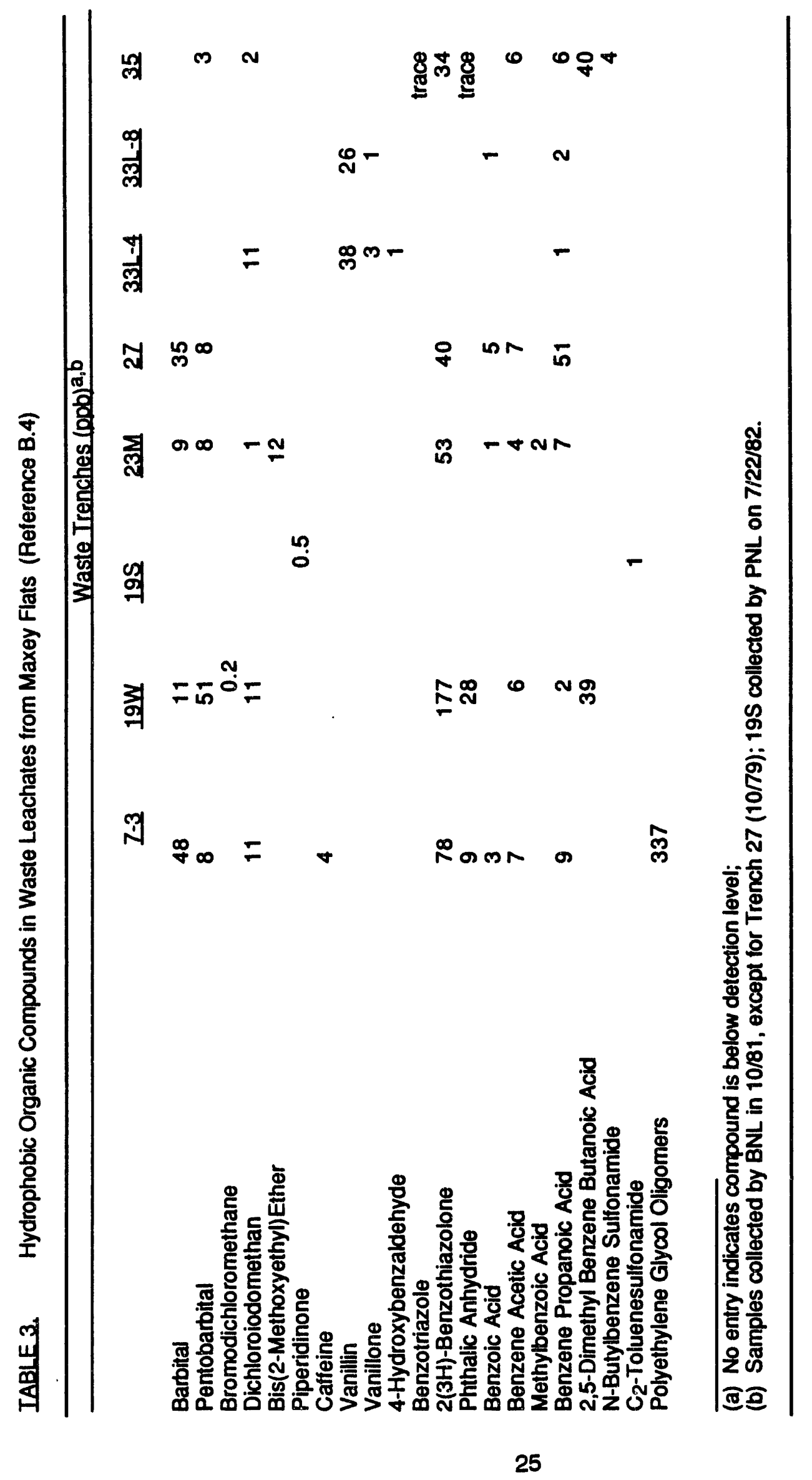




\subsubsection{Sheffield and Barnwell Low-Level Radioactive Waste Disposal Facilities}

Nonradiological testing of groundwater quality was the goal of preliminary sampling studies carried out at actual low-level radioactive waste (LLW) disposal facilities. From the data gained in these studies future facilities could be designed that would exhibit less groundwater contamination.

The LLW disposal facility at Sheffield, Illinois was selected for this sampling study because organics have previously been detected in groundwater near the site, and an extensive groundwater monitoring system was in place at the site.

The LLW disposal facility at Barnwell, South Carolina was selected for this sampling study because it is an example of an operating commercial LLW facility that practices waste classification, waste segregation, and to the extent practical, operates as required by 10 CFR Part 61, NRC's rule for LLW disposal. The site also has numerous groundwater monitoring wells.

At both sites wells were purged of standing water and allowed to recover prior to sampling. For volatile organics and the acrolein and acrylonitrile samples, two $40-\mathrm{mL}$ glass vials with teflon-lined lids were collected. For total aromatics and non-purgeable organics, a $2 \mathrm{~L}$ glass bottle with a teflon-lined lid was collected. All samples were stored at $4^{\circ} \mathrm{C}$ until analysis. Analyses were done by standard EPA methods.

At the Sheffield site, the main organic compounds found were cyclohexene, dioxane, trichloromethane, 1,1,1-trichloroethane, 1,1-dichloroethane, tetrachloroethylene, chloroform, and hydrocarbons associated with petroleum. The concentration of 1,1,1trichloroethane was over $1 \mathrm{mg} / \mathrm{mL}$ in three wells. Concentrations of other organic compounds exceeded EPA drinking water standards.

The organic chemical concentrations for the Barnwell site were low. Chloroform was found in all the sample sites with a peak concentration of $14 \mu \mathrm{g} / \mathrm{mL}$. The only other compounds identified above the detection limit were hydrocarbons associated with petroleum (B1).

\subsubsection{Analysis of Tetraphenylboron in Natural Waters}

Tetraphenylboron (TPB) is used to precipitate radioactive ${ }^{137} \mathrm{Cs}$ from high-level nuclear wastewater at the Defense Waste Processing Facility operated by the DOE at Savannah River. This use of large amounts of TPB can potentially result in a release of 
TPB into soil or aquatic environments. TPB degrades in the environment to diphenylborinic acid (DPBA) and biphenyl. Mills et al. (1988) described an analytical procedure for the analysis of DPBA and TPB in natural waters. TPB and DPBA could be cleaned from other dissolved organic matter (e.g., humic acids) by the use of $\mathrm{C}_{18}$ SepPaks . Recovery on untreated Sep-Paks was below $60 \%$. However, pretreating the Sep-Paks with $5 \mathrm{~mL}$ of $0.1 \mathrm{M}$ calcium chloride increased recovery to $>90 \%$. The quantitation was done by HPLC on a $\mathrm{C}_{18}$ column using water $(\mathrm{pH}=3$ with phosphoric acid) and acetonitrile as the mobile phase (B11.)

\subsection{OTHER MATRICES}

This section reports on matrices that do not fit under the preceding headings. We have included some papers that do not directly apply to mixed waste, but may be generally useful.

\subsubsection{Nuclear Materials}

Hydrocarbon, chlorocarbon, and partially substituted halohydrocarbon impurities in UF6 can be determined using an analytical mass spectrometer. Any peaks above background, other than those of UF6, are used to identify impurities. A 5-gram sample of liquid UF 6 is leaked into a mass spectrometer capable of measuring a mass range of 1 to 352. By comparing the intensities of impurity ions to those of UF 6 it is possible to semiquantitate the total impurity content. Some impurity fragments and their ions are listed below.

\begin{tabular}{c} 
Mass Number \\
\hline 26 \\
27 \\
31 \\
43 \\
47 \\
49 \\
69
\end{tabular}

Positivelv Chargied lon Fraoments
\[ \begin{array}{c}\mathrm{C}_{2} \mathrm{H}_{2} \\ \mathrm{C}_{2} \mathrm{H}_{3} \\ \mathrm{CF} \\ \mathrm{C}_{3} \mathrm{H}_{7} \\ 12 \mathrm{C}^{35} \mathrm{Cl} \\ 12 \mathrm{C}^{37} \mathrm{Cl} \\ \mathrm{CF}_{3}\end{array} \]

This procedure was designed to certify that a UF 6 sample contains $<0.01 \mathrm{~mol} \%$ of the potential impurities listed above. (C1)

\subsubsection{Lacoratory Matrices - Oraanic Chelates}

This subsection describes papers that have studied the chemistry of organic chelator/radionuclide interaction in laboratory-prepared samples. Simulated waste studies were made to establish the cause of gas formation in 101-SY. This paper concluded that 
there was first order kinetics for gas formation in both $\mathrm{NaAlO}_{2}$ and HEDTA. No such relationship was found in EDTA. The gas formation was linked with degradation of HEDTA. HPLC monitored the degradation of HEDTA using UV detection of the iron(III) complex (C2). The thermodynamic properties of transuranium elements with hydrophilic and hydrophobic organic chelators were reported by Nitsche and Becraft (C3). The stability constants and thermodynamic functions of PuEDTA-, PUHEDTA and PuH ${ }_{2}$ EDTA complexes have been determined by an extraction method (C4). Dai and Halz reported the use of an amperometric detector for the detection of EDTA and other chelators in nonradioactive wastewater (C5). 


\subsection{CONCLUSIONS}

With the exception of the method development activities at Hanford, and to a lesser extent at ORNL, there is only a very small body of work relating to organic analysis in radioactive wastes that can be applied to analysis of organics in the Hanford waste tanks. For the most part, the existing literature deals with analyses for components on the EPA priority pollutant list. The data obtained thus far from Hanford waste tank core samples indicate that EPA priority pollutants do not comprise a significant portion of the organic material in the waste. The other analyte that has been studied the most is the chelator class of compounds, e.g., EDTA, HEDTA, etc. Methods for detecting these tank waste components have been developed and are available for application to Hanford waste core and grab samples. Analytical techniques that have been adapted to identify primary tank organic components and their radiolytic decomposition products are not generally available; those that exist were developed through Hanford research projects. The methods developed by Toste and his co-workers for tank organic analysis, while successful in accounting for most of the organic carbon in NCRW waste, could only account for $1 \%$ of the organic carbon in double-shell slurry material. It is clear that additional methods must be made available for the analysis of organics in Hanford waste tanks. From the documents recovered through this literature review, these methods are not presently available. 


\subsection{LITERATURE CITED}

A. Nuclear Waste Samples

A1. Metcalf, S. G. 1986. Analysis of Hianford Liquid Effluents for Hazardous Waste, Regulatory Compliance - Preliminary Data. RHO-RE-SA-133-P, Rockwell Hanford Operations, Richland, Washington.

A2. Griest, W. H. 1991. "Oak Ridge National Laboratory Underground Nuclear Waste Storage Tank Characterization." Presented at the DOE National Tank Waste Characterization Workshop, June 25-27, 1991.

A3. Tomkins, B. A., J. E. Caton, W. H. Griest, et al. 1990. Anal. Chem. 62:253-257.

A4. Lucke, R. B., W. Ulbricht, S. A. Clauss, and J. A. Campbell. "Development and Validation of a Method for Collection and Analysis of Headspace Sample in Mixed Waste Storage Tanks." In 47th Northwest Regional Meeting American Chemical Society Program and Abstracts, p. 54, June 17-19, 1992, University of Montana, Missoula, Montana.

A5. Toste, A. P., T. J. Lechner-Fish, D. J. Hendren, R. D. Scheele, and W. G.

Richmond. 1988. J. Radioanal. Nuclear Chemistry, Articles 123(1):149-166.

A6. Toste, A. P., F. T. Hara, D. J. Hendren, T. J. Lechner-Fish, et al. 1987. Chemical and Radiochemical Analysis cf Hanford Radioactive Wastes. PNL-6360, Pacific Northwest Laboratory, Richland, Washington.

A7. Toste, A. P., and T. J. Lechner-Fish. 1989. "Organic Diagenesis Commercial, Low-Level Nuclear Wastes." Radioactive Waste Management and the Nuclear Fuel Cycle. Special Issue: Perspectives on National and International Programs and Technology - Part I. 12(1-4):29\%-301.

A8. Toste, A. P., R. B. Lucke, and T. J. Lechner-Fish. 1987. "Organic Analysis of Mixed Nuclear Wastes," Waste Management '87: Waste Isolation in the U.S., Technical Programs, and Public Education Series Title: Volume 3, pp. 323-330, March 11-15, 1987. CONF-870306, Tucson, Arizona.

A9. Griest, W. H., B. A. Scenley, B. A. Tomkins, et al. 1990 . Adaptation of SW-846 Methodology for the Organic Analysis of Radioactive Mixed Wastes. CONF. 900758-2, Oak Ridge, Tennessee.

A10. Tomkins, B. A., J. E. Caton, W. H. Griest, et al. 1989. Anal. Chem. 61:2751-2756.

A11. Toste, A. P., T. R. Pahl, R. B. Lucke, and R. B. Myers. 1987. "Analysis of Complex Mixtures in Nuclear Wastes." In Proceedings of the 24th Hanford Life Sciences Symposium; Health and Environmental Research on Complex Organic Mixtures, eds. Gray et al. pp. 133-150. DOE 62 Symposium Series, CONF-85 1027.

A12. Campbell, J. A., K. H. Pool, P. K. Melethil, D. Meisel, and L. J. Sears. 1992. "Analysis of Actual and Simulated Waste Samples by Derivatization GC/MS and Ion Chromatography." Presented at the 47th ACS Northwest Regional Meeting, June 17-19, 1992, University of Montana, Missoula, Montana. 
A13. Lucke, R. B., J. A. Campbell, K. L. McKeeta, and S. A. Clauss. 1991. "Analysis of Chelators and Chelator Fragments in Mixed Hazardous Wastes by Derivatization GC/MS." In Proceedings of the 39th ASMS Conference on Mass Spectrometry and Allied Topics, May 19-24, 1991, Nashville, Tennessee.

A14. Tomkins, B. A., and J. E. Caton. 1987. Preparation of Radioactive "Mixed" Waste Samples for Measurement of RCRA Organic Compounds. CONF-870763-1, Oak Ridge, Tennessee.

A15. Hoppe, E. W., J. A. Campbell, R. W. Stromatt, and M. J. Steele. 1992. "Development and Validation of a Method for Cleanup of Paraffin Hydrocarbons Containing Samples for the Analysis of Semivolatile Organic Compounds." In 47th Northwest Regional Meeting American Chemical Society Program and Abstracts, p. 53, June 17-19, 1992, University of Montana, Missoula, Montana.

A16. Hoppe, E. W., J. A. Campbell, R. B. Lucke, and G. A. Ross. 1992. "Development and Validation of a Method for Cleanup of Paraffin Hydrocarbons Containing Samples Prior to the Analysis of Volatile Organic Compounds." In 47th Northwest Regional Meeting American Chemical Society Program and Abstracts, p. 49, June 17-19, 1992, University of Montana, Missoula, Montana.

A17. Stromatt, R. W. 1989. Procedure for Extraction of Single Shell Tank Samples for the Analysis of Semivolatile Organic Compounds. PNL-ALO-120, Pacific Northwest Laboratory, Richland, Washington.

A18. DOE Methods for Evaluating Environmental and Waste Management Samples. March 1992. Method PVO30R. (Draft)

A19. DOE Methods for Evaluating Environmental and Waste Management Samples. March 1992. Method OG015R. (Draft)

A20. Spall, W. D., and W. F. Sandoval. 1992. "Modification of SW-846 Purge and Trap for Use in a Radioactive Environment." Presented at the 47th ACS Northwest Regional Meeting, June 17-19, 1992, University of Montana, Missoula, Montana.

A21. Clauss, S. A., J. A. Campbell, S. A. Bryan, R. Scheele, and S. Pedersen. Application of High Pressure Liquid Chromatography to the Analysis of Chelators in Synthetic Waste Mixtures. In preparation, Pacific Northwest Laboratory.

A22. General Procedure for the Determination of NTA, HEDTA, EDTA, and DTPA in Chelate and Metal Chelate Mixtures. RDSAP-0021, W. R. Grace and Co. Lexington Massachusetts.

A23. Unger, M., E. Mainka, and W. König. 1987. Fresenius Z. Anal. Chem. 329:50-54.

A24. Metcalf, S.G. 1981. Determination of EDTA and HEDTA in Hanford Defense Waste by High Performance Liquid Chromatography. RHO-SA-218, Rockwell Hanford Operation, Richland, Washington. 
A26. Campbell, J. A., R. B. Lucke, and S. A. Clauss. 1991. "Application of LC/MS to the Study of Chriators in Mixed Hazardous Waste." In Proceedings of the 39th ASMS Conference on Mass Spectrometry and Allied Topics, May 19-24, 1991, Nashville, Tennessee.

A27. Campbell, J. A., R. B. Lucke, H. R. Udseth, and S. A. Clauss. 1992. "Application of Electrospray Mass Spectrometry and Thermospray Liquid

Chromatography/Mass Spectrometry to the Study of Chelators and Chelator Fragments in Mixed Hazardous Wastes." In 47th Northwest Regional Meeting American Chemical Society Program and Abstracts, p. 50, June 17-19, 1992, University of Montana, Missoula, Montana.

A28. EPA SW-846, September 1986 Edition, Method 9060.

A29. Brandt, R. E. 1990. Determination of Carbon in Solutions by Combustion and Coulomatry. LA-344-105, Westinghouse Hanford Operations, Richland, Washington.

A30. Mrochek, J. E., T. M. Gilliam, and E. W. McDanial. 1986. "Grout Formulation for the Immobilization of Mixed Organic Containing Wastes." In Proceedings of the American Nuclear Society International Topical Meeting Waste Mlar iagement and Decontamination and Decommissioning, eds. J. M. Pops, I. M. Leonard, and E. J Maye, pp. 55-76. CONF-860905-Vol 1. September 14-18, 1985, Niagara Falls, Now York.

A31. Spall, W. D., and Y. C. Rodgers. 1992. "Extraction and Quantitation of Semivolatiles from the Mixed Wastes Using Supercritical Carbon Dioxide." In 47th Northwest Regional Meeting American Chemical S Jciety Program and / Sstracts, p. 54, June 17-19, 1992, University of Montana, Missoula, Montana.

A32. Leonard, K. S., D. P. Raymond, J. R. Duffield, and U. R. Williams. 1987. "Computer Simulation Modelling of Mixed Chemical/Radioactive Waste Dispusal Systems." Waste Management '87: Waste Isolation in the U.S., Technica! Programs, and Public Education Series Title: Volume 3, pp. 331-338, CONF870306. March 11-15, 1987, Tucson, Arizona.

\section{B. Environmental Samples}

B1. Goode, D. J. 1986. Nonradiological Groundwater Quality at Low Level Radioactive Waste Disposal Sites. NUREG-1183, U. S. Nuclear Regulatory Commission, Washington, D.C.

B2. Solow, A. J., and D. R. Phoenix. 1987. Characterization investigation Study Volume 2: Chemical and Radiological Analysis of Waste Pits. FMPC/Sub-008Vol.2, Roy F. Weston, Inc., West Chester, Pennsylvania. 
B3. Toste, A. P., L. J. Kirby, and T. R. Pahl. 1984. "Role of Organics in the Subsurface Migration of Radionuclides in Groundwater." Geochemical Behavior of Disposed Radioactive Waste. eds. G. S. Barney, J. D. Navratil, and W. W. Schulz, pp. 251-270. ACS Symposium Series, March 20-25, 1984, Seattle, Washington.

B4. Toste, A. P., L. J. Kirby, and T. R. Pahl. 1984 "Chemical Characteristics, Migration and Fate of Radionuclides at Commercial Shallow Land Burial Sites." In Proceedings of the Fifth Annual Participants' Informational Meeting DOE Low-Level Waste Management Program, CONF-8308106. September 11-12, 1984, Denver, Colorado.

B5. Kirby, L. J. 1982. Radionuclide Distributions and Migration Mechanisms at Shallow Land Burial Sites. NUREG/CR-2383, U. S. Nuclear Regulatory Commission, Washington, D.C.

B6. Kirby, L. J. 1984. Radionuclide Distributions and Migration Mechanisms at Shallow Land Burial Sites. NUREG/CR-3607, U. S. Nuclear Regulatory Commission, Washington, D.C.

B7. Toste, A. P., L. J. Kirby, and T. R. Pahl. 1984. "Organic Geochemical Studies at a Commercial Shallow-Land Disposal Site of Low-Level Waste." Presented at Waste Management '84, March 11-15, 1984, Tucson, Arizona.

B8. Toste, A. P. L. J. Kirby, W. H. Rickard, and D. W. Robertson. 1984.

"Radionuclide Characterization, Migration and Monitoring at a Commercial LowLevel Waste Disposal Site." In Proceedings of an International Conference on Radioactive Waste Management volume 5, International Atomic Energy Agency, pp. 213-226, IAEA-CN-43/470. Vienna, Austria.

B9 Toste, A. P., L. J. Kirby, D. W. Robertson, K. H. Abel, and R. W. Perkins. 1983. IEE Transactions on Nuclear Science NS-30(1):580-585.

B10. Kirby, L. J., A. P. Toste, and C. L. Wilkerson. 1982. "Chemical Species of Migrating Radionuclides at Shallow Land Low-Level Radioactive Waste Burial Site." In Proceedings of an International Conference on Radioactive Waste ilanagement, International Atomic Energy Agency, pp. 63-69, IAEA-SM-257/55P. Vienna, Austria.

B11. Mills, G. L., D. Schwind, and D. C. Adriano. 1988. Chemosphere 17(5):937-942.

\section{Other Matrices}

C1. Beverly, C. R. 1987. Hydrocarbons, Chlorocarbons, and Partially Substituted Hydrocarbons in Uranium Hexafluoride. Method R-25, Martin Marietta Energy Systems, Inc., Paducah, Kentucky.

C2. Delegard, C. 1980. Laboratory Studies of Complexed Waste Slurry Volume Growth in Tank 241-SY-101. RHO-LD-124, Rockwell Hanford Operations, Richland, Washington. 
C3. Nitsche, H., and K. Becraft. 1990. "The Complexation Behavior of Neptunium and Plutonium with Nitrilotriacetic Acid." Presented at the Division of Nuclear Chemistry and Technology, American Chemical Society National Meeting, August 26-31, 1990, Washington, D.C.

C4. Poczynajlo, A. 1991. J. of Radioanal. and Nuclear Chem. 148(2):295-307.

C5. Dai, J., and G. R. Helz. 1988. Anal. Chem. 60:301-305. 


\section{APPENDIXA}

REFERENCES TO MIXED WASTE ANALYSIS THAT DO NOT INCLUDE SPECIFIC PROCEDURES 
This appendix gives an overview of the concerns arising from mixed waste and mixed waste analysis. The references cited include discussion of a need for analysis of mixed wastes, or in some cases, results of analysis in mixed wastes, but contain no useful information regarding specific analytical procedures applied to the wastes.

The Resource Conservation and Recovery Act (RCRA) (1991) requires that all hazardous waste be sufficiently characterized to facilitate its safe treatment, storage, and disposal1. The U. S. Departments of Energy (DOE) and Defense (DOD) have identified a large number of facilities and sites that require characterization. Directives from DOE have required its prime contractors to characterize and remedy any deficiencies that might exist at these sites. This has required a extensive laboratory analysis effort. Samples found at DOE sites are primarily sludges, sediments, liquids and soil cores. Samples containing organic compounds are typically analyzed for priority pollutants, pesticides, and polychlorinated biphenyls (PCBs) ${ }^{2}$.

Gordon et al. (1988) discussed options for the closure of waste sites at the Savannah River Plant. At Savannah River, previous waste management practices have led to the contamination of groundwater, mainly water-table aquifers, with volatile organics, radionuclides, and other chemicals. Closure of the waste sites must be done in a manner that will mitigate the groundwater contamination. Three options were evaluated: (1) removal of the waste, (2) sealing the waste in situ, or (3) taking no action. The options were evaluated with respect to geohydrological conditions, type of waste, risk assessment, and cost. It was concluded that the risk to public human health was low, while occupational exposure for removing the waste would be high. The cost of removing the waste was aiso the highest of the three proposed options ${ }^{3}$.

In addition to the RCRA and DOE requirements another reason for the characterization of mixed waste is safety. One facility of particular concern is tank 241SY-101 (101-SY) on the Hanford site. This tank regularly vents a volume of hydrogen gas. A report by Reynolds et al. gives a good historical background on 101-SY4.

A report prepared by the PNL Tank Waste Science Panel (1991) describes the physical, radiolytic, and chemical processes in 101-SY. A process thought to generate hydrogen is the radiolytic decomposition of water by ${ }^{137} \mathrm{Cs}$. A possible chemical mechanism for the production of hydrogen involves a reaction between the chelator HEDTA and $\mathrm{NaAlO}_{2}$. Both of these compounds are known components of 101-SY. The reaction, similar to the Oppenauer oxidation, causes HEDTA to be oxidized to EDTA via a 
hydroxyaluminum-alcohol complex. A by-product of this reaction is hydrogen. Because of this, chelator analysis has become quite important 5 .

Chelating agents are also important because of their impact on the migration of radionuclides in the environment, particularly through groundwater movement. A paper by Means and Alexander (1981) discussed the environmental biogeochemistry of chelators and how this would relate to the disposal of chelated radioactive waste. The authors found that chelators can aid the migration of radionuclides in soils and can increase the uptake of radionuclides in plants. Three options for the disposal of chelated waste were proposed: (1) bind the solidified chelator waste in some solid matrix, (2) substitute biodegradable chelators for the more environmentally persistent chelators, and (3) chemically or thermally degrade the chelators prior to disposal6.

The interaction of chelators and radionuclides can change the radionuclides solubility and sorption characteristics. EDTA and HEDTA increased the solubility and decreased the sorption of all the radionuclides studied: $\mathrm{Co}, \mathrm{Sr}, \mathrm{Am}, \mathrm{Np}$, and Pu. The solubility was measured in water, and the sorption was measured on soil from around the Hanford site?.

A report by Silva (1991) describes the explosion potential of transuranic waste. The report was prepared to evaluate the safe storage of mixed waste at the Waste Isolation Pilot Plant (WIPP) project. The report gives examples of explosions and fires at several DOE facilities. In some cases organic compounds, such as xylene or petroleum ether, were implicated. In other cases inorganic materials, such as ammonium nitrate, were implicated. Silva suggested that the WIPP Final Safety Analysis Report be modified to accommodate the ignitions, fires, explosions, and drum overpressurizations that were identified 8 .

Bowerman (1985) has written two reports that discuss the organic content and the EPA regulation of low-level radioactive waste (LLW) from commercial generators. The first report lists results of a survey that was done to identify broad categories of LLW that would require special management practices. Ninety-one organizations responded to the survey. Three classes of waste were identified: wastes containing lead, wastes containing chromium, and waste containing organic liquids. The LLWs containing organic liquids are listed in Tables 4 and $5^{9}$. 
IABLE 4. Sources of Wastes Containing Organic Liquids

\begin{tabular}{ccc}
\hline $\begin{array}{c}\text { Generator } \\
\text { Type }\end{array}$ & $\begin{array}{c}\text { Volume } \\
\left(\mathrm{ft}^{3}\right)\end{array}$ & $\begin{array}{c}\text { Percent } \\
\text { Distribution }\end{array}$ \\
\hline Reactor & 2,451 & 13.7 \\
Non-reactor & & \\
academic & 5,952 & 36.5 \\
medical & 3,727 & 15.0 \\
industrial & 5,604 & 33.8 \\
Total & 17,734 & 100.0 \\
\hline
\end{tabular}

IABLE5. Waste Types Containing Organic Liquids

\begin{tabular}{lcr}
\hline Waste Type & $\begin{array}{c}\text { Volume } \\
\left(\mathrm{ft}^{3}\right)\end{array}$ & $\begin{array}{c}\text { Percent of } \\
\text { Total }\end{array}$ \\
\hline Scintillation liquids & 3,222 & 18.2 \\
Scintillation vials & 9,178 & 51.7 \\
Organic lab liquids & 3,708 & 20.9 \\
Miscellaneous solvents & 1,626 & 9.2 \\
Total & 17,734 & 100.0 \\
\hline
\end{tabular}

The second report by Bowerman (1984) reviewed the application of EPA regulations to $L W$ containing hazardous material, including organics. Organic material may be deemed hazardous because of its ignitability or toxicity. At the time of the report , the need for better definitions and waste management practices was apparent to the author ${ }^{10}$. 


\section{Beferences}

1. Resource Conservation and Recovery Act, Part B Permit Application Volume 4, Appendix C3. February 1991. DOEMIPP-91-005-Vol.4, U. S. Department of EnergyMIPP, Carlsbad, New Mexico.

2. Leventhal, L., and D. Kharkar. 1985. Trans. Am. Nucl. Soc. 50:74.

3. Gordon, D. E., C. M. King, B. B. Looney, D. E. Stephenson, and W. F. Johnson. 1988. "Environmental Analysis of Closure Options for Waste Sites at the Savannah River Plant." In Proceedings of the Ninth Annual DOE Low-Leval Waste Management Forum: Technical Session 3, Performance Assessment, pfr. 747. February 1988. Report No: CONF-870859-Pt. 3.

4. Reynolds, D. A., D. D. Siemer, D. M. Strachan, and R. W. Wallace. 1990. A Survey of Available Information on Gas Generation in Tank 241-SY-101, ed. D. M. Strachan. PNL-7520, Pacific Northwest Laboratory, Richland, Washington.

5. Tank Waste Safety Panel. 1991. Hanford Tank Safety Project. Chemical and Physical Processes in Tank 241-SY-101: A Preliminary Report. PNL-7595/AD940, Pacific Northwest Laboratory, Richland, Washington.

6. Means, J. F., and C. A. Alexander. 1981. Nucl. and Chem. Waste Mgt. 2:183196.

7. Delegard, C. H., G. S. Barney, and S. A. Gallagher. 1984. "Effects of Hanford High-Level Waste Components on the Solubility and Sorption of Cobalt, Neptunium, Plutonium, and Americium." Geochemical Behavior of Disposed Radioactive Waste, Am. Chem. Soc. Symp. Series 246, eds. G. S. Barney, J. D. Naveratil, and W. W. Schulz, pp. 95-112. Amer. Chem. Society, Washington D.C.

8. Silva, M. 1991. An Assessment of the Flammability and Explosion Potential of Transuranic Waste. EEG-48, DOE/AL/58309-48, Environmental Evaluation Group, Albuquerque, New Mexico.

9. Bowerman, B. S., C. R. Kempf, D. R. MacKenzie, B. Siskind, and P. L. Piciulo. 1985. Identification of Radioactive Mixed Waste in Commercial Low-Level Wastes. BNL-NUREG-37069, CONF-8509121-20, Brookhaven National Laboratory, Upton, New York.

10. Bowerman, B. S., and P. L. Piciulo. 1985. Application of EPA Regulations to LowLevel Radioactive Wastes. BNL-NUREG-37007; CONF-8506200-1,

Brookhaven National Laboratory, Upton, New York. 
APPENDIX B

CITATIONS FOR ANALYTE TYPES

B.1 


\section{Analyte}

Chelators (e.g., EDTA, HEDTA)

Volatile Organics

Semivolatile Organics

halocarbons

Alkyl Phenols

Normal Paraffin Hydrocarbons (NPHs)

\section{Beferences}

$A 6, A 7, A 8, A 12, A 13, A 21$,

A22, A23, A24, A26, A27, B3, B4, B5,

$B 6, B 8, B 9, B 10, C 2, C 5$

A10, A11, A14, A18, A19, A29, B30,

$\mathrm{A} 31, \mathrm{~A} 32, \mathrm{C} 3, \mathrm{C} 4$

$A 3, A 5, A 9, A 15, A 16, A 17, A 20$

$A 1, B 1, C 1$

A7, A8

A15, A16 
APPENDIXC

CITATIONS FOR METHODOLOGY TYPES

C.1 


\section{Mathodology}

gas chromatography (GC/FID, GC/FTIR, GC/MS)

liquid chromatography, HPLC

mass spectrometry (MS, GCMS,

LC/MS, thermospray, electrospray)

total organic carbon (TOC)

clean-up chroinatography

sampling techniques

intrared spectrometry (as FTIR)

coulometry

colorimetric

supercritical fluid

extraction

\section{Beferences}

$A 3, A 4, A 5, A 6, A 7, A 8, A 9, A 10$, A11, A12, A13, A14, A17, A18, A19, $A 30, B 3, B 4, B 5, B 6, B 7, B 8, B 9$, B10,

A14, A21, A22, A23, A24, A26, A27, B11, C2, C5

$A 3, A 4, A 5, A 6, A 7, A 8, A 9, A 10$, A11, A12, A13, A17, A18, A26, A27, $A 30, B 3, B 4, B 7, B 8, B 9, B 10, B 5$, $\mathrm{B6}, \mathrm{C1}$

$A 5, A 9, A 28, A 29, A 30$,

A14, A15, A16, B4 37, B8, B10

$A 1, A 2, A 4, B 1, B 2, B 3, B 4, B 5, B 6$

A11

A29

A30

A31 


\section{APPENDIXD}

DESCRIPTION OF DATABASE SEARCH

D.1 
The Chemical Abstracts on the DIALOG System were searched from 1967 to 1991. A total of 68 documents were recovered from this database as potential references. Key words searched included "MIXED," WASTE? ?," "MIXED(1N)WASTE? ?," and "ANAL (ANALYSIS, ANALYTICAL(LY))." The "?" indicates a wildcard search.

The Energy Science and Technology Database from 1974 to August of 1991 and the Nuclear Science Abstracts Database from 1948 to 1976, both on the DIALOG System, were simultaneously searched. A total of 56 documents were recovered from this database as potential references. Key words searched included "MIXED," WASTE? ?," "MIXED(2N)WASTE? ?," "ORGANIC," "ANALYSIS," and "MONITOR."

The Department of Defense Defense Research Online System (DROLS) and the Defense Technical Information.System (DTIC) were searched. A total of 106 documents were recovered from this database as potential references. Key words searched included "ANALYTICAL CHEMISTRY," RADIOACTIVE WASTES," and "ORGANIC COMPOUNDS." 


\section{APPENDIXE}

INFORMATION FROM FOREIGN SOURCES 
Inquiries concerning availability of organic analytical methodology from English and French sources was initiated through two concerns already under contract with Westinghouse-Hanford. David Snedeker, representing British Nuclear Fuels (BNFL), provided several contacts with BNFL and the United Kingdom Atomic Energy Authority (AEA). Bill Gallegher of Numatec (subsidiary of Kogema, France, a nuclear fuel cycle company) made inquiries in France.

To acquaint potential respondents with the specifics of the project's needs, a letter was provided that gave details of our organic analytical search objectives. An example of this letter, tailored for Britain, is provided in this Appendix. A similar letter was provided to Numatec in order to facilitate their inquiries.

The process of finding the right contacts through these means has proven to be very lengthy. Snedeker spoke to several BNFL contacts who told him that the subject matter, organic analysis in radioactive samples, is an esoteric one in Europe, since for the most part, EPA-type analytical requirements are not integrated into the European technical community, and operating practices are such that wastes are segregated and therefore are not as complex as the wastes at Hanford. Numatec informed me that they spent months pursuing my objectives through the wrong contacts.

Two leads to finding the extent of information available have been developed. A positive reply was received from Dr. J. S. Hislop, Divisional Manager, Analysis and Diagnostics Division, AEA Technology. The AEA operates as much as possible on a commercial basis, and Dr. Hislop responded with an offer to determine the nature and extent of information available at AEA for a week's technical effort. Arrangements are being made to contract with AEA for this work.

Numatec, after following several unsatisfactory leads, has located an agent in France, Robert Boshwitz, with the technical background and contacts to pursue the project objectives. Mr Boshwitz has visited Hanford and is familiar with the Hanford waste storage problems. He has offered to develop information as to the type and extent of information available through his contacts at the French atomic energy agency, CEA. If there is sufficient information, he will negotiate a contract to provide literature and a detailed report. Unfortunately, his first attempts have been rebuffed, and he is attempting to gain entrée through ex-CEA staff. The prognosis for rapid success through this route does not appear to be good. 
If these efforts result in discovering an extensive, or important European database on organic analyses in radioactive wastes, it is recommended that additional effort be made to assemble foreign information. Time should be allowed for locating the appropriate European agents and agencies in England, France, Germany, and perhaps Russia, and sufficient time and funds be made available to contract with these agents to recover the related literature and report on their findings. The efforts made during the course of the project have indicated that such information, to the extent that it exists, is not readily available, and will require time, patience, effort, and persistence to procure. From the work performed by this project, it appears that the information available through United States sources fairly summarizes the extent of knowledge in the area. 


\title{
EXAMPLE OF LETTER OF INQUIRY SENT TO FOREIGN CONTACTS
}

\author{
Battelle, Pacific Northwest Laboratory \\ P.O. Box 999 \\ Richland, Washington, USA 99352
}

(509) 376-8834

FAX (509) 376-2329

\section{Dear Addressee:}

Pacific N r thwest Laboratory (PNL) is a contractor for the US Department of Energy and is working closel;' with Westinghouse Hanford Company (WHC) in the management and cleanup of nuclear defense wastes at the Hanford Reservation in the State of Washington. My group at PNL is responsible for the development of analytical methods for organic compounds present in nuclear wastes, so that they can be accounted for and dealt with as necessary before final treatment and disposal of the wastes is accomplished. The specific task I am presently charged with is to survey procedures for analysis of organic constituents in radioactive materials, and to prepare a summary report including procedures from Hanford as well as off-site sources. Although there are published methods for analysis of organics in wastes, notably methods from our US Environmental Protection Agency, they do not include provisions for handling radioactivity, do not include all compounds of interest, and often are not applicable to the sample matrices found in nuclear wastes.

Your name was given to me by David F. Snedeker, Marketing Manager for the Northwest USA, BNFL, inc., as someone who might work with me to develop information on the status of development of methods for organics in radwastes. I realize that such information might be only available from those engaged in active research iri the area. I am, therefore, asking that if you do not feel able to contribute to my study, you give this letter to, and put me in touch with someone who has an active interest in these matters.

Specifically, I need to be put in touch with persons who can provide me with formal, preferably published methods for determination of organics in radionuclear waste and reprocessing streams. A partial list of organic analyte types will include:

- Total organic carbon

- Molecular waight distribution of organics

- Solvents (carbon tetrachloride, tetrachloroethylene, hexone, saturate hydrocarbons, etc.)

- Volatile organics (e.g., purge\&trap and related methods)

- Low molecular weight acids and aldehydes (glyoxylic acid, oxalic acid, glyoxal, acetic acid, etc.)

- Chelators and chelator breakdown products (EDTA, HEDTA, NTA, IDA, ED3A, etc.)

- Phenolic compounds

- General methods for determination of semivolatile acid, base and neutral organic compounds

- Higher molecular weight organics (polymers, humic acids, condensation products 
- Organometallic compounds

- Nitroso compounds

This is only a hurriedly assembled list to get the process started. ! am also interested in publications specifically directed to the use of mass spectrometry (MS), gas chromatography/MS (GC/MS), liquid chromatography/MS (LC/MS), and LC/MS interfaces that are particularly applicable to rad wastes. Also ion chromatography applied to organics in rad wastes, and simultaneous detection of organic and inorganic eluants from separation columns, for example by combined ICP/MS and GC/MS or LC/MS.

In addition, any research results arising from a general study of the organic composition of radionuclear and rad processing wastes would be greatly appreciated.

As you can see, I am not looking for recipes as much as I am looking for the collective experience of Analytical Chemist colleagues who have studied the organic chemistry of rad wastes. We do not want to undertake expensive method development operations for sample matrices and organic analytes that have already been studied in depth.

I expect this will be an iterative process; I will be happy to enter into a letter, phone or FAX dialogue with any number of interested colleagues. Should there be sufficient interest in these matters in Europe, perhaps in future an international conference on analysis of organics in rad wastes might be considered.

Thanks for your help.

Roger M. Bean, Ph. D.

Staff Scientist

Group Leader, Advanced Organic Analytical Methods 


\section{DISTRIBUTION}

No. of

Copies

\section{OFFSITE}

12 DOE/Office of Scientific and Technical Information

J. Tseng

U.S. Department of Energy

Forrestal Building, MS EM-30

1000 Independence Avenue

Washington, DC 20585

C. Abrams 1987 Virginia

Idaho Falls, ID 83404

E. C. Ashby

225 North Avenue

Boggs Chemistry Building

Georgia Institute of Technology

Atlanta, GA 30332

K. Bandyopadhyay

Building 129

Brookhaven National Laboratory

Upton, NY 11973

N. E. Bibler

Westinhouse Savannah River Co.

Bldg. 773A, Room 108

Aiken, SC 29802

D. Campbell

Oak Ridge National Laboratory

P.O. Box 2008, MS 6268

Oak Ridge, TN 37831-6268

F. Carlson

6965 North, 5th West

Idaho Falls, ID 83401

P. d'Entremont

Westinghouse Savannah River

P.0. Box 616, Bldg. 703-H

Aiken, SC 29802

R. Daniels

SAIC

20030 Century Blvd.

Suite 201

Germantown, MD 02161
No. of

Copies

M. First

295 Upland Avenue

Newton Highlands, MA 02161

C. Forsberg

Room 24-109

77 Massachusetts Avenue

Cambridge, MA 02139

E. J. Hart

2115 Hart Road

Port Angeles, WA 98362

P. Hogroran

SAIC

20030 Century Blvd., Suite 201

Germantown, MD 20874

E. P. Horwitz

Chemistry Division

Argonne National Laboratory

Argonne, IL 60439

A. Hoskins

WINCO, MS-5217

P.O. Box 4000

Idaho Fails, ID $83403-4000$

B. Hudson

Lawrence Livermore National

Laboratory, L-221

P.O: Box 808

Livermore, CA 94550

M. Kazimi

Room 24-201

77 Massachusetts Avenue

Cambridge, MA 02139

P. Kiang

BDM, Trevion I, Suite 300

12850 Middlebrook Road

Germantown, MD 20874

T. Kress

P.O. Box 2009

MS 8088, Building 9108

Oak Ridge, TN 37831

Distr. 1 
No. of

Copies

T. Larson

Los Alamos National Laboratory, M-1

P.O. Box 1663, MS C-920

Los Alamos, NM 87545

D. Moisel

Argonne National Laboratory

9700 South Cass Avenue

Argonne, IL 60439

D. Oakley

Los Alamos National Laboratory

University of California, Suite 310

409 12th Street, SW

Washington, DC 20024-2188

D. Ploetz

West Valley Nuclear Services Co.

P.O. Box 191, MS 305

West Valley, NY 14171-0191

M. Reich

Building 129

Brookhaven National Laboratory

Upton, NY 11973

G. A. Russel

Department of Chemistry

lowa State University

Ames, lowa 50011-3111

J. Saveland

20030 Century Blvd., Suite 201

Germantown, MD 20874

G. Schmauch

Air Products \& Chemicals, Inc.

7201 Hamilton Blvd.

Allentown, PA 18195-1501

W. W. Shulz

727 Sweetleaf Drive

Wilmington, DE 19808

B. Schutte

EG\&G Idaho, Inc.

P.O. Box 1625

Idaho Falls, ID 83415-3940
No. of

Copies

D. D. Siemer

WINCO

IRC, MS 2207

Idaho Falls, ID 83403

S. Slezak

Sandia National Laboratory

Division 6463

P.O. Box 5800

Albuquerque, NM

H. Sullivan

Los Alamos National

Laboratory, N-6, MS-K557

P.O. Box 1664

Los Alamos, NM 87545

C. Terrell

U.S. Department of Energy

Building 704-S

P.O. Box A

Aiken, SC 29801

W. J. Thomson

Department of Chemical

Engineering

Washington State University

Pullman, WA 99164

A. S. Veletsos

5211 Paisley

Houston, TX 77096

G.B. Wallis

Thayer School of Energy

Darmouth College

Hanover, NH 03755

H. Walter

U.S. Department of Energy

Trevion II, EM-343

Washington, DC 20545

M. Walter

U.S. Department of Energy

Trevion II, EM-343

Washington, DC 20545

Distr. 2 
No. of

\section{Copies}

D. Wiffen

U.S. Department of Energy

Trevion II, EM-35

Washington, DC 20845-0002

G. Woodall

U.S. Department of Energy

785 DOE Place, MS-1139

Idaho Falls, ID 83402

R. L Zollar

Department of Chemical Engineering

Washington State University

Pullman, Washington 99163

\section{ONSITE}

7 DOE Richland Field Office

S. O. Branch, A4-02

R. R. Christensen, A4-02

R. E. Gerton, A5-21

N. G. McDuffie, B2-42

G. Rosenwald, A5-21

B. J. Tucker, A4-35

Reading Room, A1-65

42 Westinghouse Hanford Companv

H. Babsd, B2-15

D. G. Baide, R1-51

D. B. Bechtold, T6-50

M. L. Bell, T5-50

R. M. Black, R1-19

R. J. Bliss, B3-04

W. F. Brehm, N2-01

T.M. Burke, H0-34

R. J. Cash, B3-68

G. L. Dunford, R1-51

K. A. Gasper, B3-68

W. H. Hamilton, R2-40

D. L. Herting, T6-50

J. G. Hill, R2-12

G. D. Johnson, L5-03 (5)

N. W. Kirch, R2-11

W. L. Knecht, HO-34

W. D. Leggett, L5-04 (5)

J. W. Lentsch, R2-78

R. M. Marusich, H5-32

L. D. Muhlestein, N1-28

A. F. Noonan, R2-12

G. W. Osboume, R2-78
No. of

Copies
D. A. Reynolds, R2-11 (5)
W. G. Ruff, R2-53
D. D. Stepnewski, N1-31
M. H. Shannon, B1-35
D. A. Tumer, H1-63
W. I. Winters, T6-50
D. D. Wodrich, R2-23

34

Pacific Nonthwest Laboraton

R. M. Bean, P8-08

S. A. Bryan, P7-35

L. L. Burger, P8-25

D. M. Camaioni, K2-10

J. A. Campbell, P8-08

S. A. Clauss, P8-08 (5)

T. H. Dunning, K2-18

M. A. Gerber, P8-38

S. C. Goheen, P8-08

B. M. Johnson, Jr., K5-02

M. R. Kreiter, K7090

R. B. Lucke, P8-08

G. B. Mellinger, P7-18

L. G. Morgan, P8-07

D. A. Nelson, P8-38

L. R. Pederson, K2-44

J. L. Ryan, P7-25

W. D. Samuels, K2-44

R. D. Scheele, P7-25

G. F. Schiefelbein, P8-38

J. C. Spanner, K2-31

D. M. Strachan, K2-44

R. W. Stromatt, P7-22

H. H. Van Tuyl, P7-22

Publishing Coordination

Technical Report Files (5) 
